\title{
VII
}

\section{A EDUCAÇÃO SUPERIOR E A CRESCENTE DESIGUALDADE SOCIAL NO BRASIL EM TEMPOS NEOLIBERAIS*}

\author{
Valdemar Sguissardi
}

Não se pode abordar a educação em geral e, em especial, a educação superior de um país sem situá-las nas suas estreitas relações com o contexto socioeconômico em que se inserem (SGUISSARDI, 2015).

\section{Introdução}

Há sete anos, julho de 2013, ao escrever para uma coletânea - que seria publicada no Brasil e na Alemanha (SGUISSARDI, 2015) - sobre o tema da educação superior (ES) no Brasil, tendo como eixos de análise as desigualdades sociais, o processo de mercantilização desse nível de educação e os desafios de sua regulação estatal de caráter público, concluía-se, com algum fio de esperança, que se houvesse alguma reversão positiva na democratização da ES, a partir de avanços na democratização do país - redução da desigualdade social, por exemplo - isto possivelmente dependesse do sucesso das mobilizações populares que estavam, então, apenas se iniciando no país.

Tais mobilizações, que se iniciaram motivadas por bandeiras de luta de esquerda - grita pela redução do valor das passagens do transporte urbano, entre outras -, aos poucos tiveram sua direção tomada por lideranças de direita, com apoio da grande mídia, e de oposição ao governo federal $-4^{\circ}$ mandato do Partido dos Trabalhadores, coligado com um leque de partidos de centro-direita, centro, centro-esquerda e esquerda. Três anos depois, essas manifestações, ampliadas, com reforço da Presidência da Câmara dos Deputados e anuência do Poder Judiciário, conduziram ao impeachment presidencial em 31/08/2016. Em decorrência deste - visto por muitos juristas como um efetivo golpe de Estado - assumiu o poder, até o final do segundo mandato da presidente deposta (Dilma Rousseff/2014-2018), um grupo político de direita e, em outubro de

* DOI - 10.29388/978-65-86678-40-6-0-f.195-235 
2018, foi eleito, para assumir o poder em janeiro de 2019, um presidente com claros traços políticos de extrema direita. Sob o aspecto econômico, poder-seia caracterizar os quase dois anos e meio do governo interino (set/2016-dez/ 2018) como sendo de acentuados traços neoliberais, e um governo de princípios e ações avançados a partir de janeiro de 2019. ${ }^{1}$ Para demonstrá-lo, tanto naquele como neste caso, bastaria apresentar sucintamente ao leitor algumas das principais Emendas Constitucionais e Leis aprovadas pelo Congresso Nacional (CN), desde o impeachment de 2016 até 2020, e o teor de uma das PEC’s que estão em tramitação atualmente neste mesmo $\mathrm{CN}$, de iniciativa do Poder Executivo ou de parlamentares.

Ainda em dezembro de 2016, três meses após esse impeachment, foi promulgada pelo $\mathrm{CN}$, por proposta do Presidente interino Temer, a Emenda Constitucional (EC) n. 95 (BRASIL, 2016), que instituiu o Novo Regime Fiscal no âmbito dos Orçamentos Fiscal e da Seguridade Social da União, segundo o qual impôs-se o congelamento, por 20 anos, das despesas primárias do Poder Executivo Federal, entre as quais as destinadas à saúde e à educação. Essas despesas somente podem sofrer reajustes anuais de acordo com a inflação do período medida pelo IPCA (Índice Nacional de Preços ao Consumidor Amplo). Chama a atenção especialmente o fato de que os montantes anuais do Orçamento da União destinados ao pagamento de juros, encargos e amortizações da dívida pública ao sistema financeiro, que costumam girar em torno de $45 \%$ do total, não são objeto de tal congelamento, podendo, inclusive, esses percentuais, ser aumentados no caso de eventual excesso de arrecadação. ${ }^{2}$

\footnotetext{
${ }^{1} \mathrm{O}$ mais importante ministro do Governo Bolsonaro tem sido sempre apresentado, tanto pelo Presidente como pela imprensa, como sendo, ao lado do Ministro da Justiça, Sérgio Moro (exjuiz da Operação Lava Jato), o Ministro da Economia Paulo Guedes. Paulo Guedes é graduado em Economia pela UFMG, Mestre e Doutor em Economia pela Chicago University, onde pontificava, então, o expoente neoliberal Milton Friedman. De retorno de Chicago e após um período de docência na PUC-Rio, Paulo Guedes convidado pelo chefe do Depto de Economia da Universidade do Chile, que viria ser o Ministro de Economia do General Pinochet, passou longos anos como membro da equipe econômica desse Governo ao lado de seu ministro da Economia. Entre outras de suas experiências, no Chile, consta sua participação no implemento da Reforma da Previdência daquele país. Observe-se que sua primeira grande atuação, como Ministro da Economia do Gov. Bolsonaro, foi a da defesa da Proposta de Emenda Constitucional (PEC) da Reforma da Previdência, muito assemelhada à Reforma Chilena, reforma que acabaria com a Previdência Social Brasileira de modelo "solidário" e propunha substituí-la uma Previdência de modelo de "capitalização" ou individual (vide mais adiante no texto).

${ }^{2}$ Uma das principais consequências da EC-95, para o campo da educação, é a inviabilização de diversas das metas do Plano Nacional de Educação (PNE)-2014-2024, dentre as quais a que previa a destinação, para este campo, até 2024, de 10\% do Produto Interno Bruto (PIB), percentual que hoje gira em torno de $5 \%$.
} 
Em 31 de março de 2017, foi aprovada a lei n. 13.429, que estabeleceu a terceirização irrestrita do trabalho, isto é, tanto para atividades complementares (legislação já existente) como para as essenciais (BRASIL, 2017a). Em 13 de julho de 2017 foi aprovada a Lei n. 13.467, da Reforma Trabalhista (BRASIL, 2017b), que alterou mais de 100 artigos da Consolidação das Leis do Trabalho (CLT), retirando muitos dos direitos dos trabalhadores. ${ }^{3}$ É preciso anotar que esta perda de direitos trabalhistas agravou-se ainda mais com a edição da Medida Provisória (MP) 905, de 11 de novembro de 2019, que criou nova forma de contratação dos trabalhadores, com o que também se promove o subemprego. ${ }^{4}$

Em 12 de novembro de 2019, foi promulgada a Emenda Constitucional (EC) n. 103, que altera o sistema vigente de previdência social e estabelece um conjunto de regras de transição. Tanto a EC 103, promulgada, quanto a anterior PEC 287/2016 - tentativa inconclusa do Governo Temer de Reforma da Previdência Social -, visaram substituir o modelo previdenciário solidário, vigente no país - em que os beneficiários são financiados por todos os trabalhadores da ativa -, por um regime denominado de capitalização, em que cada trabalhador seria responsável pela formação de uma "poupança" que garantiria sua futura previdência, além de aumento de idade mínima de aposentadoria e outras mudanças. Essa "poupança” seria administrada por bancos públicos ou privados que lucrariam, por muitos e muitos anos, e de modo costumeiramente exorbitante, no mercado financeiro, enquanto os trabalhadores (e apenas os empregados) teriam, igualmente como de regra, correções de sua poupança extremamente limitadas.

3 1) Acordos coletivos (com participação do sindicato) sobre jornada de trabalho passam a depender de acordos individuais sem participação sindical; 2) As férias que podiam ser divididas em dois períodos podem agora ser divididas em três; 3) Instituiu-se o trabalho intermitente, isto é, contratos de trabalho não contínuos, pagos por hora; 4) A contribuição sindical passou a ser opcional; 5) Mulheres grávidas e lactantes poderão trabalhar em ambiente insalubre desde que o risco - baixo ou médio - seja atestado por médico da empresa; 6) Restrição de acesso à justiça gratuita: o trabalhador terá que pagar os honorários do empregador e as custas processuais, caso falte a audiências e perca ações trabalhistas; 7) Não serão mais considerados parte da jornada de trabalho as atividades no âmbito da empresa como descanso, estudo, alimentação, interação entre colegas, higiene pessoal e troca de uniforme; 8) Os planos de cargos e salários não precisam constar do contrato de trabalho e nem ser homologados pelo Ministério do Trabalho, mas apenas negociados entre patrões e trabalhadores, podendo ser mudados constantemente; 9) O tempo gasto pelo trabalhador, de ida e volta ao trabalho, não fará parte da jornada de trabalho; 10) Fim da assistência gratuita na rescisão do contrato de trabalho.

4 Entre outras mudanças: 1) Instituiu-se a Carteira Verde e Amarela: os trabalhadores contratados por meio dela não terão os direitos previstos na CLT e nas Convenções Coletivas, com salários de até um Salário Mínimo e meio, isto é, serão subempregados; 2) O FGTS será reduzido, de $8 \%$ para $2 \%$ ao mês e a multa por demissão sem justa causa cairá de $40 \%$ para $20 \%$; 3) Férias, $13^{\circ}$ Salário e FGTS serão parcelados em até 12 parcelas... 
Após cerca de cinco meses de tramitação e debates no $\mathrm{CN}$, foi aprovada a EC 103, sem seu traço mais temido pelos trabalhadores - a "capitalização" - mas com profundas alterações no regime vigente até então. ${ }^{5}$ Essas mudanças são tão profundas e tão prejudiciais aos trabalhadores necessitados dos benefícios previdenciários que o Ministro da Economia sempre alardeou que sua aprovação, nos termos em que o foi, geraria, em 10 anos, uma economia de cerca de $\mathrm{R} \$ 800$ bilhões aos cofres da União.

Entre as PEC's em tramitação no CN, de iniciativa do Poder Executivo/Ministério da Economia, vale a pena fazer referência à PEC 188/2019-Senado, também conhecida como do "Pacto Federativo", que Nelson C. Amaral, em detalhada análise de suas 12 medidas, considera como a que melhor expressa "A dimensão ultraliberal do grupo no poder federal" e se constituiria em "Um desastre para as políticas sociais brasileiras" (AMARAL, 2020, p. 197).

Em sua análise, Amaral começa por afirmar que esta PEC propõe uma série de mudanças à Constituição Federal de 1988 (CF-1988) mediante a alteração, inclusão ou exclusão de artigos, parágrafos, assim como, ao revogar diversos de seus dispositivos. A dimensão "ultraliberal" do grupo no poder, proponente desta PEC, revelar-se-ia, por exemplo,

[...] ao não querer estabelecer planos plurianuais, desvincular o máximo possível os recursos financeiros associados às políticas sociais, e transferir para estados, Distrito Federal e municípios as responsabilidades para que haja a diminuição das desigualdades sociais; por outro lado, ao gerir os recursos do fundo público, arrecadados da população brasileira, transfere recursos públicos para o setor privado realizar ações sociais e protege, com todas as liberações possíveis, as despesas financeiras associadas ao capital financeiro (AMARAL, 2020, p. 198).

A seguir, com base no resumo da análise de Nelson Amaral desta PEC 188 e de forma quase ipsis litteris, algumas das alterações à CF-1988 preconiza-

\footnotetext{
51) Aumento da idade mínima para aposentadoria: 62 anos de idade e 15 de contribuição para as mulheres e 65 anos e 20 anos de contribuição para os homens (regra pouco diversa para servidores públicos, e algumas outras poucas profissões como professores e policiais); 2) Mudança significativa no cálculo do benefício, que não poderá ser inferior ao salário mínimo mas nem superior a $\mathrm{R} \$ 5.839,45$ mensais hoje; 3) As alíquotas passarão a ser progressivas, ou seja, quem ganha mais pagará mais, indo de $7,5 \%$ a $22 \%$; 4) Mudança nas regras da pensão por morte: $50 \%$ do valor da aposentadoria, mais 10\% por dependente até completar 100\% (há exceções); 5) Há limitação quando houver acúmulo de benefício; 6) Foi estabelecido um conjunto grande de regras de transição.
} 
das por esta PEC: 1) Fim da vinculação dos recursos financeiros para a saúde e educação, de forma independente, isto é, passaria a haver uma vinculação acoplada entre os recursos financeiros aplicados em saúde e educação; 2) Fim dos programas suplementares de material didático, escolar, transporte, alimentação e assistência à saúde, pela União, os quais deverão ser executados pelos estados, Distrito Federal e municípios, com recursos da Contribuição do Salário-Educação que, segundo esta PEC seriam totalmente transferidos para estes entes federados; 3) Fim da obrigação de os entes federados expandirem a rede pública de educação, podendo os recursos públicos ser aplicados em escolas privadas; 4) Quando o endividamento público exceder as despesas de capital, poderá haver redução dos salários e da carga de trabalho dos servidores públicos dos entes federados - União, estados e Distrito Federal e município -, redução que poderá chegar a $25 \%$, além de que, fica estabelecido por esta PEC que os salários dos servidores públicos não terão mais reajustes anuais obrigatórios; 5) Propõem-se regras adicionais às da EC 95/2016, no que concerne ao congelamento das despesas primárias obrigatórias, isto é, quando estas atingirem $95 \%$ do total, será suspenso seu reajuste pela inflação do período anterior como previsto por essa EC; 6) Revogam-se os artigos 46 a 60 da Lei 12.351 de 22/12/2010 que definiu o Fundo Social do pré-sal e que destinava parte dos recursos financeiros da exploração do petróleo e gás natural para a saúde e educação, e, portanto, os percentuais estabelecidos pela Lei 12.858 de 9/09/2013 que destinava $75 \%$ dos recursos para a educação básica e $25 \%$ para a saúde; 7) Revoga-se o Art. $5^{\circ}$ da Lei Complementar 141, de 13/01/2012, retirando-se, portanto, a vinculação dos recursos aplicados nas ações de saúde da população aos crescimento do PIB; 8) Ao lado dos direitos sociais constitucionais - saúde, educação, alimentação, trabalho, moradia, etc. - propõe-se a criação do "direito ao equilíbrio fiscal intergeracional” que, eventualmente, poderá ser utilizado, pelos governantes, para bloquear a satisfação plena daqueles direitos; 9) Revoga-se a obrigatoriedade da elaboração de Planos Plurianuais; 10) Propõem-se formas de intervenção na atual autonomia dos entes federados, como, por exemplo, na distribuição de recursos associados ao petróleo e gás natural, que seria vinculada a "[...] indicadores de resultados dos estados, Distrito Federal e municípios”, etc (AMARAL, 2020, p. 198-201).

Uma série de outras PEC's e Medidas Provisórias estava em tramitação em 2019 e início de 2020, tratando dos mais diferentes temas, entre as quais as referentes à reforma tributária, que deverão acentuar ainda mais as marcas neo- 
liberais extremadas dos detentores do poder desde o impeachment de 2016 e de suas políticas socioeconômicas.

Nesse texto, acima referido, de julho de 2013, como destacado na epígrafe, escrevia-se que "Não se pode abordar a educação em geral e, em especial, a educação superior de um país sem situá-las nas suas estreitas relações com o contexto socioeconômico em que se inserem" (SGUISSARDI, 2015).

Tanto em 2013 como hoje, essa diretriz metodológica permanece válida e com total pertinência teórico/explicativa. Então, examinavam-se as relações entre as desigualdades sociais e educacionais; a expansão privado/mercantil e oligopolizada da ES; e as vicissitudes da regulação de caráter público no âmbito de um Estado semipúblico ou semiprivado. Neste texto, pretende-se mostrar como, desde o impeachment presidencial (ago/2016) até a passagem de 2019/2020 - assim como vem ocorrendo há décadas ou desde o Império -, a ES continua a manter uma bastante estreita relação com a imensa desigualdade social no país e, assim, eventualmente, a reproduzi-la e a contribuir para, a seu modo, agravar a ausência de efetiva democracia na sociedade brasileira que se traduz, especialmente, por essa crescente desigualdade.

Antes de tudo, é preciso enfatizar que não é democrática uma sociedade em que são incomensuráveis as desigualdades sociais e infinitas as diferenças de oportunidades, por exemplo, de acesso à ES dos indivíduos pertencentes às suas diferentes classes sociais. Se nos ativermos apenas ao campo educacional, nem metade da população brasileira de 15 a 18 anos conclui sequer o ensino médio e cerca de $80 \%$ dos jovens de 18 a 24 anos têm sequer acesso a qualquer uma das cerca de 2.500 instituições de ES, das quais, mais de 2.000 são simples faculdades isoladas distribuídas por todo o território nacional, e, muitas delas, gratuitas ou a cobrar preços aparentemente módicos. Como se verá, o acesso de apenas cerca de $1 / 5$ da população da faixa etária adequada à educação superior depende muito menos de disposição/vontade de ordem familiar ou pessoal do que de absoluta falta de condições socioeconômicas da imensa maioria da população.

\section{Uma amostra da imensa desigualdade social brasileira}

Seis brasileiros concentram a mesma riqueza que os 100 milhões mais pobres do país, cerca de metade da população brasileira (A distancia que nos une, Oxfam-Brasil). 
O Brasil era, em 2019, um dos cinco países mais populosos do mundo (cerca de 210 milhões de habitantes) e um dos dez de maior Produto Interno Bruto (R $\$ 7,3$ trilhões ou cerca de US\$ 1,5 trilhões), mas, ao mesmo tempo situava-se entre os dez primeiros, dentre os cerca de 200 países do mundo, em desigualdade social, de que a concentração de renda é um dos seus principais aspectos, como se verá adiante.

Quanto à composição étnico-racial atual da população brasileira e sua evolução (abreviada) desde o fim oficial do regime escravocrata (13/05/1888), observem-se os dados da tabela 1 abaixo.

É importante observar as mudanças ocorridas nos últimos 19 anos, de 2000 a 2019: se, em 2000, a população autodeclarada branca era 8,4 pontos percentuais mais numerosa do que a dos afrodescendentes (pretos e pardos); em 2019, são os autodeclarados afrodescendentes que se sobrepõem aos brancos em 13,4 pontos percentuais. Uma mudança de 21,8 pontos percentuais.

Tabela 1 - Composição étnico-racial no Brasil segundo os Censos Demográficos de 1890, 2000 e Pnad 2019

\begin{tabular}{ccccccc}
\hline \hline Ano & $\begin{array}{c}\text { População } \\
\text { (Milhões) }\end{array}$ & $\begin{array}{c}\text { Branca } \\
\mathbf{\%}\end{array}$ & $\begin{array}{c}\text { Preta } \\
\mathbf{\%}\end{array}$ & $\begin{array}{c}\text { Parda } \\
\mathbf{\%}\end{array}$ & $\begin{array}{c}\text { Indígena } \\
\mathbf{\%}\end{array}$ & $\begin{array}{c}\text { Amarela } \\
\mathbf{\%}\end{array}$ \\
\hline \hline $\mathbf{1 8 9 0}$ & 14 & 44,0 & 14,6 & $32,4^{* *}$ & $9,0^{*}$ & - \\
$\mathbf{2 0 0 0}$ & 170 & 53,4 & 6,1 & 38,9 & 0,4 & 0,5 \\
\hline $\mathbf{2 0 1 9}$ & 210 & 42,8 & 9,4 & 46,8 & 0,4 & 1,1 \\
\hline \hline
\end{tabular}

Fonte: Montagem do autor a partir de dados da Revista Retratos, IBGE, n. 11, de maio de 2018. Para 2019, os dados são da Pnad (autodeclaração).

* Nos censos de 1890 teria sido utilizado o termo cabocla em referência à etnia-raça indígena. ** No censo de 1890 , em lugar de parda, utilizou-se o termo mestiça.

A concentração de renda, como traço essencial da desigualdade social, pode ser demonstrada de diversas formas. Os gráficos abaixo - o 1, que compara a participação dos 10\% mais ricos do país com os dos EUA, China e França; e o 2, que mostra a participação na renda nacional dos $10 \%$ mais ricos, dos $40 \%$ intermediários e dos 50\% mais pobres - bastariam para mostrar tal concentração. 
Gráfico 1 - Desigualdade resiliente: participação dos 10\% mais ricos na renda nacional por país, em percentual

\section{DESIGUALDADE RESILIENTE}

Participação dos $10 \%$ mais ricos na renda nacional por país, em \%

Brasil $=$ China EUA Erança

56,6

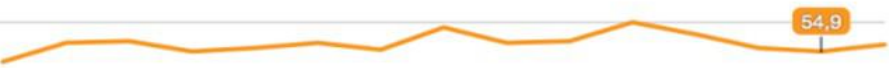

50,0

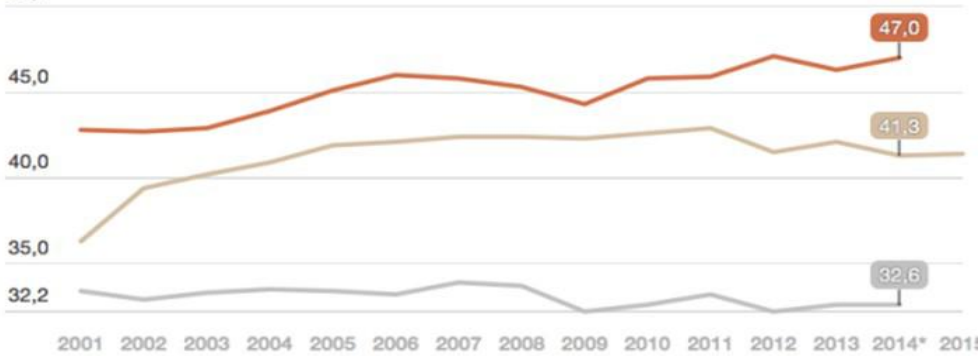

•Últimos dados disponiveis dos EUA e França Fonte: World Wealth and Income Database

Fonte: Costa (2017)

Gráfico 2 - Participação na renda nacional no Brasil em percentual

\section{PARTICIPAÇÃO NA RENDA NACIONAL NO BRASIL}

Em \%

$10 \%$ mais ricos $40 \%$ intermediários $50 \%$ mais pobres

56,6

50

40

30

20

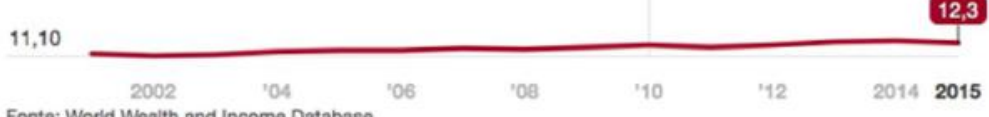

Fonte: World Wealth and Income Database

Fonte: Costa (2017). 
Outro modo de demonstrar a desigualdade social e a concentração de renda que lhe é própria é via apresentação escalonada do rendimento domiciliar per capita, com base nos dados da Síntese dos Indicadores Sociais (SIS) do Instituto Brasileiro de Geografia e Estatística (IBGE), como se faz com as tabelas 2 e 3 abaixo.

Tabela 2 - Rendimento domiciliar per capita no Brasil de 2012 a 2018

\begin{tabular}{|c|c|c|c|c|c|c|c|}
\hline \multirow{2}{*}{$\begin{array}{l}\text { Rendimen- } \\
\text { to domicili- } \\
\text { ar per capi- } \\
\text { ta }\end{array}$} & \multicolumn{7}{|c|}{ Número de Pessoas } \\
\hline & 2012 & 2013 & 2014 & 2015 & 2016 & 2017 & 2018 \\
\hline $\begin{array}{l}\text { Sem rendi- } \\
\text { mento }\end{array}$ & 1.975 .290 & 1.793 .241 & 1.607 .704 & 1.824 .543 & 2.248 .477 & 2.473 .068 & 2.492 .916 \\
\hline $\begin{array}{l}\text { Maior que } 0 \\
\text { e menor ou } \\
\text { igual a } 1 / 4 \\
\text { S.M. }\end{array}$ & 21.530 .661 & 20.124 .149 & 17.684 .744 & 19.056 .338 & 21.667 .142 & 21.433 .256 & 22.020 .758 \\
\hline $\begin{array}{l}\text { Maior que } \\
1 / 4 \text { e menor } \\
\text { ou igual a } \\
1 / 2 \text { S.M. }\end{array}$ & 39.703 .329 & 37.857 .310 & 36.977 .192 & 37.707 .222 & 38.428 .516 & 36.683 .842 & 36.562 .768 \\
\hline $\begin{array}{l}\text { Maior que } \\
1 / 2 \text { e menor } \\
\text { ou igual a } 1 \\
\text { S.M. }\end{array}$ & 59.258 .700 & 60.372 .447 & 61.494 .678 & 61.629 .008 & 60.913 .286 & 58.735 .365 & 58.791 .269 \\
\hline $\begin{array}{l}\text { Maior que } 1 \\
\text { e menor ou } \\
\text { igual a } 2 \\
\text { S.M. }\end{array}$ & 45.629 .199 & 47.819 .760 & 49.637 .861 & 50.073 .569 & 48.648 .866 & 53.789 .229 & 52.974 .465 \\
\hline $\begin{array}{l}\text { Maior que } 2 \\
\text { e menor ou } \\
\text { igual a } 3 \\
\text { S.M. }\end{array}$ & 13.431 .972 & 13.947 .430 & 15.273 .188 & 14.799 .071 & 14.717 .304 & 15.044 .497 & 15.788 .468 \\
\hline $\begin{array}{l}\text { Maior que } 3 \\
\text { e menor ou } \\
\text { igual a } 5 \\
\text { S.M. }\end{array}$ & 8.691 .276 & 9.763 .201 & 10.048 .150 & 10.136 .350 & 9.811 .536 & 9.686 .183 & 10.594 .893 \\
\hline $\begin{array}{l}\text { Maior que } 5 \\
\text { S.M. }\end{array}$ & 7.308 .573 & 7.770 .711 & 8.440 .446 & 7.500 .899 & 7.971 .873 & 8.037 .471 & 8.725 .206 \\
\hline Total & 197.529.000 & 199.249.000 & 200.963 .000 & 202.727.000 & 204.407 .000 & 206.089 .000 & 207.743.000 \\
\hline
\end{tabular}

Fonte: Síntese de Indicadores Sociais - SIS, IBGE.Disponível em: <www.ibge.gov.br/ estatisticas/sociais/populacao/9221-sintese-de-indicadores-sociais.html? edicao $=18830 \& \mathrm{t}=$ download $>($ Elaboração de Nelson C. Amaral $)$ 
Tabela 3 - Rendimento domiciliar per capita no Brasil de 2012 a 2018

\begin{tabular}{|c|c|c|c|c|c|c|c|}
\hline \multirow{2}{*}{$\begin{array}{l}\text { Rendimento domici- } \\
\text { liar per capita }\end{array}$} & \multicolumn{7}{|c|}{ Percentual } \\
\hline & 2012 & 2013 & 2014 & 2015 & 2016 & 2017 & 2018 \\
\hline Sem rendimento & 1,0 & 0,9 & 0,8 & 0,9 & 1,1 & 1,2 & 1,2 \\
\hline $\begin{array}{l}\text { Maior que } 0 \text { e menor } \\
\text { ou igual a } 1 / 4 \text { S.M. }\end{array}$ & 10,9 & 10,1 & 8,8 & 9,4 & 10,6 & 10,4 & 10,6 \\
\hline $\begin{array}{l}\text { Maior que } 1 / 4 \text { e me- } \\
\text { nor ou igual a } 1 / 2 \text { S.M. }\end{array}$ & 20,1 & 19,0 & 18,4 & 18,6 & 18,8 & 17,8 & 17,6 \\
\hline $\begin{array}{l}\text { Maior que } 1 / 2 \text { e me- } \\
\text { nor ou igual a } 1 \text { S.M. }\end{array}$ & 30,0 & 30,3 & 30,6 & 30,4 & 29,8 & 28,5 & 28,3 \\
\hline $\begin{array}{l}\text { Maior que } 1 \text { e menor } \\
\text { ou igual a } 2 \text { S.M. }\end{array}$ & 23,1 & 24,0 & 24,7 & 24,7 & 23,8 & 26,1 & 25,5 \\
\hline $\begin{array}{l}\text { Maior que } 2 \text { e menor } \\
\text { ou igual a } 3 \text { S.M. }\end{array}$ & 6,8 & 7,0 & 7,6 & 7,3 & 7,2 & 7,3 & 7,6 \\
\hline $\begin{array}{l}\text { Maior que } 3 \text { e menor } \\
\text { ou igual a } 5 \text { S.M. }\end{array}$ & 4,4 & 4,9 & 5,0 & 5,0 & 4,8 & 4,7 & 5,1 \\
\hline Maior que 5 S.M. & 3,7 & 3,9 & 4,2 & 3,7 & 3,9 & 3,9 & 4,2 \\
\hline
\end{tabular}

Fonte: Síntese de Indicadores Sociais - SIS, IBGE. Disponível em: $<$ www.ibge.gov.br/estatisticas/sociais/populacao/9221-sintese-de-indicadores-sociais.html?edicao $=18830 \& \mathrm{t}=$ download $>$ (Elaboração de Nelson C. Amaral)

Além dos números absolutos (tabela 2), observe-se a repartição do rendimento domiciliar per capita, no curso desses sete anos, pelos percentuais por eles representados (tabela 3).

Entretanto, deve-se assinalar que o Salário Mínimo vigente em fevereiro de 2018 , de $\mathrm{R} \$ 954,00$, corresponde a menos de $1 / 3$ do salário mínimo ideal que segundo o Departamento Intersindical de Estatística e Estudos Socioeconômicos (Dieese) deveria ser de $\mathrm{R} \$ 3.683,67$ ou 3,86 vezes aquele. De acordo com a Constituição Federal de 1988, o SM deveria suprir a sexta básica e necessidades de moradia, saúde, educação, vestuário, higiene, transporte, lazer e previdência (BRASIL ECONÔMICO, 2018b).

Tomando por base os dados da tabela 2 e dividirmos a população entre as pessoas de todas as idades que viviam (sobreviviam) com até um SM e os que viviam com mais de um SM, teremos: 
Tabela 4 - Rendimento domiciliar per capita no Brasil de 2012 a 2018

\begin{tabular}{l|r|r|r|r|r|r|r}
\hline \hline $\begin{array}{l}\text { Rendimento domiciliar per capi- } \\
\text { ta }\end{array}$ & \multicolumn{7}{|c}{ Percentual } \\
\cline { 2 - 8 } & $\mathbf{2 0 1 2}$ & $\mathbf{2 0 1 3}$ & $\mathbf{2 0 1 4}$ & $\mathbf{2 0 1 5}$ & $\mathbf{2 0 1 6}$ & $\mathbf{2 0 1 7}$ & $\mathbf{2 0 1 8}$ \\
\hline $\begin{array}{l}\text { Sem rendimento, maior que 0 e } \\
\text { menor ou igual a 1 S.M. }\end{array}$ & 62,0 & 60,3 & 58,6 & 59,3 & 60,3 & 57,9 & 57,7 \\
\hline $\begin{array}{l}\text { Maior que 1 e menor ou igual a 5 } \\
\text { S.M. }\end{array}$ & 34,3 & 35,9 & 37,3 & 37,0 & 35,8 & 38,1 & 38,2 \\
\hline Maior que 5 S.M. & 3,7 & 3,9 & 4,2 & 3,7 & 3,9 & 3,9 & 4,2 \\
\hline \hline
\end{tabular}

Fonte: Síntese de Indicadores Sociais - SIS, IBGE (Elaboração do autor com base nos dados da tabela 3).

Se tomado por base o SM ideal (Dieese) e somados os dados das duas últimas linhas da tabela 3 acima, ter-se-ia apenas de 7\% a 8\% da população com rendimento per capita superior ao SM constitucional.

\section{Pnud - IDH}

Dentre os 189 países do mundo que têm aferido, pelo Programa das Nações Unidas para o Desenvolvimento (Pnud), seu Índice de Desenvolvimento Humano (IDH) - com base em indicadores de saúde, educação e renda -, o Brasil ocupava, em 2018, a 79ª posição, com um IDH de 0,761. Na América do Sul situava-se em $4^{\circ}$ lugar, empatado com a Colômbia, bastante distante dos três primeiros: Chile $\left(42^{\circ}\right)$, Argentina $\left(48^{\circ}\right)$ e Uruguai $\left(57^{\circ}\right)($ G1.GLOBO.COM, 2019).

Entretanto, a situação do país é muito mais grave quando se verificam os dados do Pnud quanto ao IDH "ajustado às desigualdades" de uma lista de 150 países. Neste caso o Brasil, com índice de 0,574, passa a ocupar a posição $102^{\mathrm{a}}$.

$\mathrm{Na}$ América do Sul, o país foi o segundo que mais perdeu no IDH [2018] devido ao ajuste realizado pela desigualdade, ficando atrás apenas do Paraguai (que foi da posição $98^{\mathrm{a}}$, com 0,724 , para a posição $112^{\mathrm{a}}$, com 0,545) (Ibidem). ${ }^{6}$

\footnotetext{
${ }^{6}$ Ao fazer este tipo de classificação, o Pnud apresenta indicadores para medir a distribuição de renda entre a população: "participação na renda dos $40 \%$ mais pobres, participação na renda dos $10 \%$ mais ricos e participação na renda dos $1 \%$ mais ricos. Com esse dado, o relatório apontou que quase um terço de todas as riquezas do Brasil estão concentradas nas mãos dos 1\% mais ricos. É a segunda maior concentração de renda do mundo, ficando atrás apenas do Catar"
} 
O Pnud avalia também as disparidades de gênero - via Índice de Desenvolvimento de Gênero - em 166 países. "O IDH para mulheres mostrou que as brasileiras estão em melhores condições de saúde e educação que os homens, mas ficam abaixo quando o assunto é renda bruta". (Ibidem). As mulheres têm em média 8,1 anos de estudo contra 7,6 dos homens, "[...] entretanto, a renda nacional bruta per capita da mulher é $41,5 \%$ menor que a do homem. Em dólares, este valor equivale a US\$ 10.432 por ano contra US\$17.827 para os homens" (Ibidem). A isto deve-se acrescentar o índice maior de desemprego e subemprego feminino em relação ao masculino, como se verá adiante.

\section{Coeficiente de Gini}

Outra forma de medir a desigualdade social de um país é por meio da aferição do Coeficiente ou Índice de Gini. Seus indicadores são a renda, a riqueza e a educação. Quanto mais próximo de 1, maior a desigualdade e vice-versa.

Segundo Daniela Amorim, de O Estado de S. Paulo (2020), a desigualdade de renda proveniente do mercado de trabalho alcançou patamar recorde no ano de 2019. Em termos anuais, a desigualdade apontada pelo Índice Gini, crescia desde o ano de 2015 até 2019, chegando neste ano ao índice de 0,629 ante 0,6279 no ano anterior, $2018 .^{7}$

\section{Desemprego e subemprego}

Os dados de desemprego e subemprego de 2018 permaneceram bastante estáveis até meados de 2019. Esses, portanto, serão tomados como referência.

Segundo dados do IBGE, reportados pelo site Brasil Econômico (2018), em meados desse ano faltaria trabalho para 27,6 milhões de pessoas no Brasil, isto é, para cerca de $28 \%$ da população economicamente ativa que era um pouco superior a 100 milhões de pessoas. Este número “[...] faz parte da taxa de subutilização da força de trabalho composta por desempregados e subocupados por insuficiência de horas" (BRASIL ECONÔMICO, 2018) . Há

(G1.GLOBO.COM, 2019).

7“'O levantamento leva em consideração os microdados sobre rendimentos e ocupação da Pesquisa Nacional por Amostra de Domicílios Contínua (Pnad Contínua), apurados pelo Instituto Brasileiro de Geografia e Estatística (IBGE)" (AMORIM, 2020). 
expressivas diferenças regionais: enquanto no estado de Piauí esta taxa beirava os $40 \%$, em Santa Catarina era de $10,9 \%$.

Os "desalentados", isto é, os que desistiram de tentar uma vaga de emprego, somavam $4,4 \%$ da força de trabalho, ou cerca 4,5 milhões de pessoas, a mais alta taxa da série histórica desde 2012. No estado de Alagoas, informa o site Brasil Econômico (2018), essa taxa chegou a 16,6\%, quase quatro vezes a média nacional. Em Santa Catarina essa taxa era de apenas 0,7\%.

O desemprego, no segundo trimestre de 2018, era de 13 milhões de pessoas, (12,4\%). Entretanto, a distribuição das taxas por estado e região são muito desiguais: no estado do Amapá foi de 21,3\%, em Alagoas, 17,3\%, e em Santa Catarina, 6,5\%, e Mato Grosso do Sul, 7,6\%, isto é, aqueles muito acima e este muito abaixo da média nacional de 12,4\% (BRASIL ECONÔMICO, 2018).

O gráfico 3 abaixo, com dados do IBGE/Pnad Contínua, mostra a evolução da taxa de desocupação, no Brasil, de jan-fev-mar de 2012 a jan-fevmar de 2020. A menor taxa verificou-se no último trimestre de 2013 e a maior no primeiro trimestre de 2017, prevendo-se sua superação a partir do segundo trimestre de 2020 em razão, especialmente, da pandemia da Covid-19.

\section{Gráfico 3 - Taxa de desocupação, por sexo, do $1^{\circ}$ trimestre de 2012 ao $1^{\circ}$ trimestre de 2020}

Taxa de desocupação, por sexo, $1^{\circ}$ trimestre 2012 - $1^{\circ}$ trimestre 2020

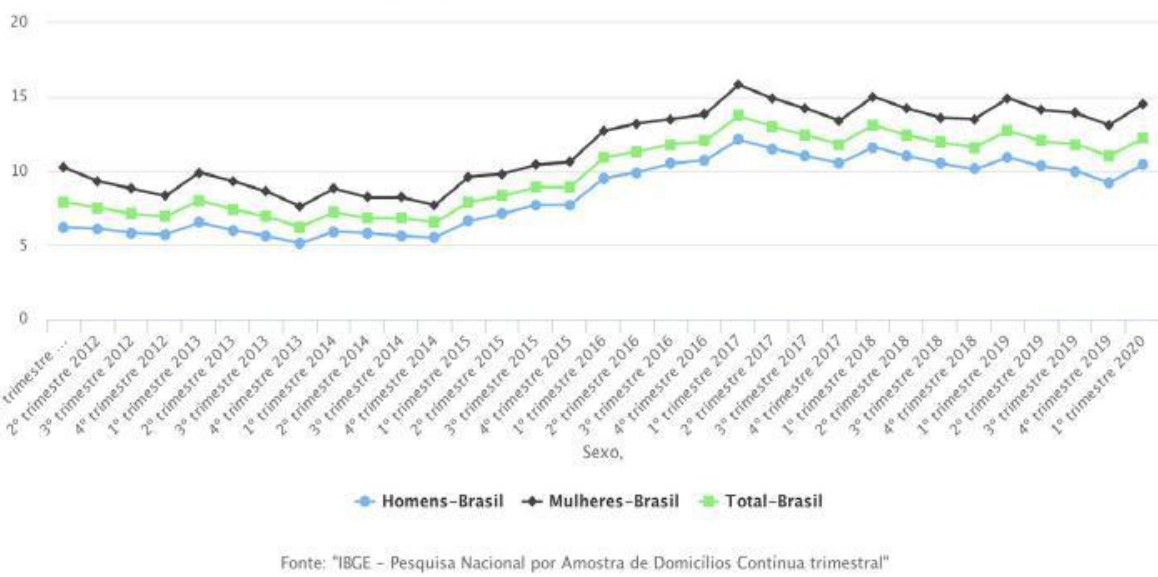

Fonte: IBGE - Pesquisa Nacional por Amostra de Domicílios Contínua trimestral (2020). 
Como se pode observar, os dados do gráfico 3 acima confirmam os dados do Pnud ao avaliar as disparidades de gênero - via Índice de Desenvolvimento de Gênero. Nos 8 anos ou cerca de 30 trimestres os índices de desocupação feminina são, com pequenas variações, $40 \%$ maior do que os índices de desocupação masculina.

No segundo trimestre de 2018, as mulheres eram a maioria em idade de trabalhar: $52,4 \%$ do total e em todas as regiões. Entretanto, de cada 100 empregados, 56,3 eram homens e, no Norte, eles eram 60,2\%. Do total de desempregados (12,4\%), o índice de desemprego masculino era de $11 \%$ e o feminino, de $14,2 \%$, isto é, $29 \%$ maior que o masculino.

Outro e mais contundente aspecto da desigualdade social é representado pelo desemprego entre pretos e pardos que é significativamente maior que o dos brancos. Em 2018, segundo trimestre, dos 12,9 milhões de desocupados/ desempregados, $52,3 \%$ eram pardos, $35 \%$ brancos e $11,8 \%$, pretos. Nesse período a força de trabalho era assim composta: $47,9 \%$ eram pardos; $42,4 \%$, brancos; e 8,5\%, pretos. A desigualdade étnico/racial revela-se também na taxa de desemprego: para uma média anual, em 2018, de 12,4\%, a taxa dos autodeclarados brancos foi de $9,9 \%$; dos pretos, de $15 \%$; e dos pardos, de 14,4\% (BRASIL ECONÔMICO, 2018).

Outros dados mostram como as questões de gênero e étnico/raciais são constitutivas da desigualdade social brasileira.

Aos dados referidos quando se tratou do IDH, vale a pena ainda acres centar que, ao se justaporem gênero e cor da pele, surgem novas diferenças. Por exemplo, em 2018, 23,5\% das mulheres brancas tinham ensino superior completo, mais do que o dobro das mulheres pretas e pardas que eram apenas $10,4 \%$ a possuí-lo.

Estas diferenças acentuam-se quando a variável analisada é o salário: segundo o IBGE, "mesmo trabalhando e estudando mais, as mulheres continuam recebendo salários inferiores aos dos homens [...] elas ganham, em média, 76,5\% do rendimento dos homens" (BRASIL ECONÔMICO, 2018a). Essa diferença seria ainda maior quando se considera o mercado de trabalho de portadores de diplomas de ensino superior completo: o salário das mulheres corresponderia a apenas $63,4 \%$ do dos homens.

Acrescente-se a isto a denominada dupla jornada de trabalho feminina: as mulheres dedicavam em média 18 horas semanais aos afazeres domésticos e cuidados pessoais contra 10 horas dos homens (73\% a mais). 
Por fim, quanto à violência, segundo o Atlas da Violência (IPEA, 2020), para um total de 56,6\% de afrodescendentes na população, em 2018, os seus membros perfaziam $75 \%$ das mortes por assassinato (57.956) no país nesse ano. E do total de mulheres assassinadas, também nesse ano (4.519 ou uma a cada duas horas), das quais mais de $30 \%$ por feminicídio, $68 \%$ eram negras.

\section{Desigualdade social e a educação superior no Brasil}

Só existirá democracia no Brasil no dia em que se montar no país a máquina que prepara as democracias. Essa máquina é a da escola pública (ANÍSIO TEIXEIRA).

Tanto intelectuais educadores quanto organismos internacionais de diversos campos, ao longo da história e, em especial, dos últimos séculos têm creditado à educação pública o condão de fazer avançar a democracia. Isto vale es pecialmente para a educação básica, mas desde pelos menos o início do Século XIX, com a universidade de Humboldt, também se poderia estender este vaticínio à ES.

Entretanto, se lançarmos um olhar cuidadoso sobre a história e evolução da educação básica e da superior no Brasil, veremos que nem aquela, nem especialmente - esta, foi tomada como uma prioridade na construção seja da democracia, seja do país como nação.

No caso da educação básica, foi apenas na Constituição Federal de 1988 que se reconheceu sua primeira fase - do ensino fundamental - como um direito subjetivo, isto é, que compromete o Estado em suas diferentes instâncias com sua oferta universal. $\mathrm{O}$ ensino médio não goza dessa prerrogativa. $\mathrm{E}$ muito menos a ES. Esta, aliás, iniciada no país, na forma de faculdades, logo após a vinda da família imperial, em 1808, fugindo das tropas napoleônicas, para a então Colônia de Portugal, apenas começou a organizar-se na forma de universidade, mais de um século depois, em 1920, com a Universidade do Rio de Janeiro (hoje, centenária Universidade Federal do Rio de Janeiro). Pode-se afirmar que a ES no Brasil, desde o Império e mesmo ao longo da República até os anos bastante recentes foi sempre marcada pelo elitismo, "[...] seja para garantir a qualificação dos funcionários do Estado, seja para garantir a supremacia da(s) classe(s) dominante(s) na acumulação do capital e manutenção do controle do poder" (SGUISSARDI, 2014, p. 208). 
A massificação da ES que ocorreu nos EUA no início do século XX e os grandes avanços ocorridos mesmo em países vizinhos, como Argentina, Uruguai e Chile, antes e após a II Guerra Mundial, não foram acompanhados no Brasil que, apenas nos últimos anos, vê o percentual de $15 \%$ a $20 \%$ de taxa líquida de matrícula ${ }^{8}$ na ES ser alcançado. Em país em que pouco mais de $50 \%$ de seus jovens de 15 a 18 anos conseguem concluir o ensino médio, segunda fase da educação básica, e em que cerca de 85\% das instituições de educação superior (IES) são privadas, das quais cerca 60\% com fins lucrativos, e em que a ES não é vista pelos poderes constituídos como uma prioridade, não é de estranhar que quase $80 \%$ dos jovens de 18 a 24 anos estejam fora de qualquer uma das suas mais de 2.500 IES.

Em Estudo Diagnóstico da Política de Expansão da (e Acesso à) Educação Superior no Brasil - 2002-2012 (SGUISSARDI, 2014), para o Conselho Nacional de Educação, afirmava-se que:

A contraposição de interesses públicos e privado-mercantis, (...) no âmbito do Estado, muito provavelmente explique por que o direito à ES se mantenha como um direito fundamental de proteção mais frágil e por que sua cobertura da área é tão diminuta e sua qualidade tão desigual: alta para uma minoria e baixa para a maioria dos que, supostamente privilegiados, a frequentam (SGUISSARDI, 2014, p. 208).

Hoje, entretanto, diante da realidade exposta na introdução deste texto sobre os acentuados ou extremados traços neoliberais dos governos de turno desde o impeachment/golpe de agosto/2016, pode-se afirmar que os interesses privado-mercantis se acentuam no âmbito do Estado e explicam a ausência de expansão da ES pública e a continuidade da expansão do setor privado em nível nacional.

Os dados do Censo de Educação Superior do Inep/MEC dos anos recentes até 2018, da PNAD Contínua e de outros estudos servirão para se estabeleçam aspectos dessa relação pretendida como objetivo deste estudo.

\footnotetext{
8“A taxa líquida de matrícula (TLM) na educação superior é um indicador de acesso ao sistema educacional por uma população considerada na idade de referência para cursar um determinado nível de ensino. Em sua definição clássica, a TLM considera apenas o percentual da população de uma faixa etária matriculada em um nível de ensino em relação ao tamanho total da população nessa faixa etária" (BRASIL, 2020). No caso da ES, a faixa etária considerada apropriada é de 18 a 24 anos.
} 


\section{A evolução da educação superior durante a ditadura e nos três mandatos presidenciais pós-ditadura}

A tabela 5 mostra a evolução das matrículas da ES no Brasil durante o período da ditadura militar - 1964-1985. Em 1964 eram apenas 164 mil matrículas, sendo 61\% públicas e 38\% privadas. Nos 10 primeiros anos - 1964-1974 - houve um crescimento de $559 \%$, alcançando-se quase um milhão de matrículas (937.593), mas invertendo-se praticamente os percentuais público/privados: 36,4\% públicos e $63,5 \%$ privados. A década seguinte - 1974-1984 - foi de baixo crescimento: apenas $49 \%$, ou menos de 10 vezes o da década anterior, com pequeno aumento do percentual público: 40,9\% contra 59,1\%. Entretanto, no total dessas duas décadas, para um aumento total de $882,9 \%$, as matrículas públicas cresceram $552,3 \%$ e as privadas, quase três vezes mais, $1.412,5 \%$.

Tabela 5 - Evolução das matrículas da ES brasileira por categoria administrativa (pública e privada) - 1964-1984

\begin{tabular}{c|c|c|c|c|c}
\hline \hline \multirow{2}{*}{ Ano } & \multirow{2}{*}{ Total } & \multicolumn{2}{|c|}{ Matrículas públicas } & \multicolumn{2}{c}{ Matrículas privadas } \\
\cline { 3 - 6 } & & Total & $\mathbf{\%}$ & \multicolumn{1}{l}{ Total } & \% \\
\hline \hline $\mathbf{1 9 6 4}$ & 142.386 & 87.665 & $\mathbf{6 1 , 6}$ & 54.721 & $\mathbf{3 8 , 4}$ \\
\hline $\mathbf{1 9 7 4}$ & 937.593 & 341.028 & $\mathbf{3 6 , 4}$ & 596.565 & $\mathbf{6 3 , 5}$ \\
\hline $\mathbf{1 9 8 4}$ & 1.399 .539 & 571.879 & $\mathbf{4 0 , 9}$ & 827.660 & $\mathbf{5 9 , 1}$ \\
\hline \hline $\mathbf{1 9 6 4 / 1 9 7 4 \Delta \%}$ & $\mathbf{5 5 8 , 5}$ & $\mathbf{2 8 9 , 0}$ & - & $\mathbf{9 9 0 , 1}$ & - \\
\hline $\mathbf{1 9 7 4 / 1 9 8 4 \Delta \%}$ & $\mathbf{4 9 , 3}$ & $\mathbf{6 7 , 7}$ & - & $\mathbf{3 8 , 7}$ & - \\
\hline $\mathbf{1 9 6 4 / 1 9 8 4 \Delta \%}$ & $\mathbf{8 8 2 , 9}$ & $\mathbf{5 5 2 , 3}$ & - & $\mathbf{1 . 4 1 2 , 5}$ & - \\
\hline \hline
\end{tabular}

Fonte: BRASIL. MEC/Inep. Sinopse Estatística da Educação Superior, 2010. Tabela organizada pelo autor em Sguissardi (2014).

A tabela 6 mostra a evolução tanto do número de instituições como de matrículas da ES públicas e privadas no período pós-ditadura, dos governos Sarney (1985-1989), Collor de Mello (1990-1992), Itamar Franco (1992-1994) e Fernando H. Cardoso - FHC (1995-1998).

Este período de 14 anos foi marcado por um baixo crescimento tanto do número de instituições quanto de matrículas, embora estas tenham sido significativamente superiores àquelas. Durante os governos Sarney, Collor de Mello e Itamar Franco (1985-1994), o índice de crescimento das instituições chegou a ser negativo, tendo o índice de matrículas crescido apenas $21,5 \%$. As ma- 
trículas públicas e privadas tiveram índices bastante próximos, com leve vantagem para as públicas: $24 \%$ contra $19,7 \%$.

Tabela 6 - Evolução do número de instituições e de matrículas de ES por categoria administrativa (público e privada) - 1985-1998

\begin{tabular}{|c|c|c|c|c|c|c|c|c|c|c|}
\hline \multirow[b]{2}{*}{ Ano } & \multicolumn{5}{|c|}{ Número de Instituições } & \multicolumn{5}{|c|}{ Número de Matrículas } \\
\hline & Total & Públ. & $\%$ & Priv. & $\%$ & $\begin{array}{l}\text { Total } \\
\text { (mil) }\end{array}$ & $\begin{array}{l}\text { Públ. } \\
\text { (mil) }\end{array}$ & $\%$ & $\begin{array}{l}\text { Priv. } \\
\text { (mil) }\end{array}$ & $\%$ \\
\hline 1985 & 859 & 233 & 27,1 & 626 & $\overline{72,9}$ & 1.367 & 2557 & $4 \quad 40,7$ & 810 & $\overline{59.3}$ \\
\hline 1994 & 851 & 218 & 25,6 & 633 & 74,4 & 1.661 & 691 & 41,6 & 970 & 58,4 \\
\hline 1998 & 973 & 209 & 21,4 & 764 & 78,6 & 2.125 & 804 & 37,8 & 1.321 & 62,2 \\
\hline $\begin{array}{c}1985-1994 \\
\Delta \% \\
\end{array}$ & 00,9 & 06,4 & - & "01,1 & - & 21,5 & 24,0 & - & $\begin{array}{l}19,7 \\
\end{array}$ & - \\
\hline $\begin{array}{c}1994-1998 \\
\Delta \%\end{array}$ & 14,3 & 04,1 & - & 20,7 & - & 27,9 & 16,5 & - & 36,2 & - \\
\hline $\begin{array}{c}1985-1998 \\
\Delta \%\end{array}$ & 13,3 & 10,3 & - & 22,0 & - & 55,4 & 44,3 & - & 63,1 & - \\
\hline
\end{tabular}

Fonte: BRASIL. MEC/Inep. Sinopse Estatística da Educação Superior, 2010. Tabela organizada pelo autor em Sguissardi (2014).

É no primeiro governo FHC (1995-1998) que, com crescimento total das instituições de $14,3 \%$ e das matrículas de $27,9 \%$, o crescimento das instituições públicas foi negativo $(-04,1 \%)$ contra um expressivo crescimento das instituições privadas $(20,7 \%)$, e o das matrículas públicas $(16,5 \%)$ foi menos de metade do das privadas $(36,2 \%)$.

Fica evidente, no período, um baixo crescimento no número de instituições $(13,3 \%)$, especialmente, devido ao decréscimo do número das públicas $(-10,3 \%)$, e um crescimento mediano nas matrículas, em que as matrículas privadas crescem cerca de 20 pontos percentuais a mais que as públicas, além de as instituições privadas terem tido $22 \%$ de aumento em seu número.

\section{A evolução do número de IES e de matrículas de 1999 a 2018 e o processo de privado/mercantilização da educa- ção superior no Brasil}

Embora se reconheça, na Constituição Federal de 1988, a possível existência de "escolas" com finalidade lucrativa, caberá ao Decreto 2.207/97, em 
seu artigo $3^{\circ}$, quando estabelece que "As entidades mantenedoras com fins lucrativos submetem-se à legislação que rege as sociedades mercantis, especialmente na parte relativa aos encargos fiscais, parafiscais e trabalhistas" e, especialmente, ao Decreto 2.306/97, a definição legal da existência de instituições de educação superior e respectivas mantenedoras com fins lucrativos, ao este decretar em seu artigo $7^{\circ}$ :

As instituições privadas de ensino, classificadas como particulares em sentido estrito, com finalidade lucrativa, ainda que de natureza civil, quando mantidas e administradas por pessoa física, ficam submetidas ao regime da legislação mercantil, quanto aos encargos fiscais, parafiscais e trabalhistas, como se comerciais fossem, equiparados seus mantenedores e administradores ao comerciante em nome individual.

Como se verifica na tabela 7 (abaixo), no ano de 1999, apenas passado pouco mais de um ano do Decreto 2.306/97, das 905 IES privadas - 82,5\% do total de 1.097 IES do país - 136 (12,4\% do total das IES do país) já haviam alterado seus estatutos (com aprovação do Ministério da Fazenda) de IES sem fins lucrativos para IES com fins lucrativos.

A aprovação da Lei de Diretrizes e Bases da Educação Nacional (Lei 9.394/96) e os Decretos 2.207/97 e 2.306/97 foram determinantes, por um lado, do aumento bastante importante do número de IES que passam de 1.097, em 1999, para 2.365, em 2010, com o triplo de crescimento das IES privadas em relação às públicas; por outro, do excepcional crescimento, entre as IES privadas, das IES com fins lucrativos que de 136 (12\% do total do país) em 1999 passam para 946 (40\%) em 2010. Em 11 anos as IES privado/mercantis apresentam um percentual de aumento de 696\% contra apenas 48\% das sem fins lucrativos e $44,8 \%$ das públicas. 
Tabela 7 - Evolução do número de IES por categoria administrativa: pública (federal, estadual, municipal) privada (Com fins lucrativos - CFL; Sem fins lucrativos - SFL) e Especiais* - Brasil - 1999-2018

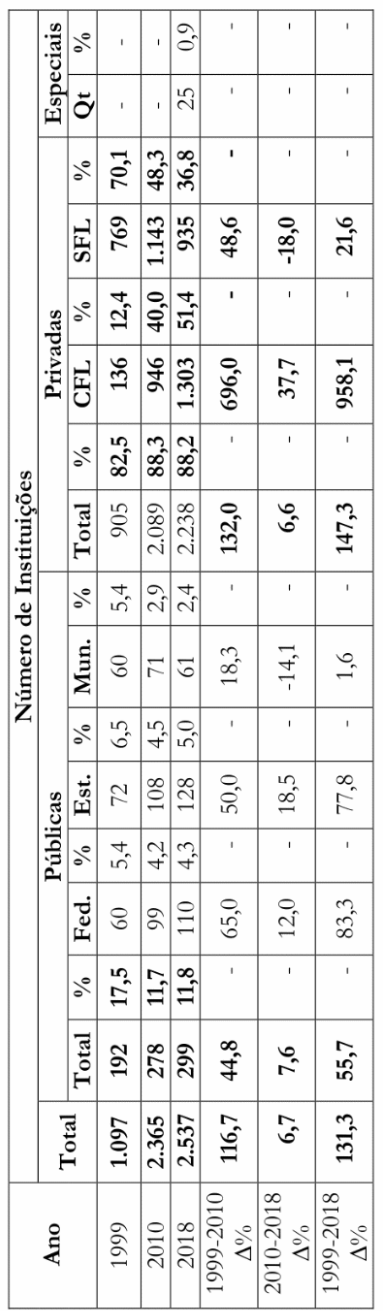

* Portaria Normativa $n^{\circ}$ 40, de 12 de dezembro de 2007: Especial (art. 242 da Constituição Federal) - instituição educacional oficial criada por lei estadual ou municipal e existente na data da promulgação da Constituição Federal, que não seja total ou preponderantemente mantida com recursos públicos, portanto não gratuita.

Fonte: Microdados do Censo da Educação Superior 1999, 2010 e 2018. Disponível em: <www.inep.gov.br/microdados> (contribuição de Nelson Cardoso Amaral). 
Tabela 8 - Evolução do número de matrículas de ES por categoria administrativa: pública (federal, estadual, municipal) privada (Com fins lucrativos - CFL; Sem fins lucrativos - SFL) e Especiais* - Brasil - 1999-2018

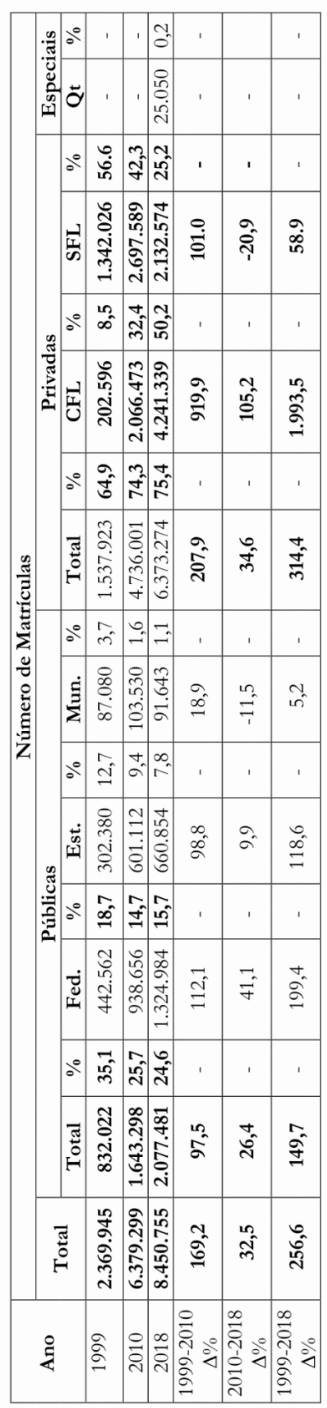

* Portaria Normativa n ${ }^{\circ}$ 40, de 12 de dezembro de 2007: Especial (art. 242 da Constituição Federal) - instituição educacional oficial criada por lei estadual ou municipal e existente na data da promulgação da Constituição Federal, que não seja total ou preponderantemente mantida com recursos públicos, portanto não gratuita.

Fonte: Microdados do Censo da Educação Superior 1999, 2010 e 2018. Disponível em: $<$ www.inep.gov.br/microdados> (contribuição de Nelson Cardoso Amaral). 
O grande salto da expansão das IES no país, como mostra a tabela 7, deu-se entre 1999 a 2010. Nos oito anos seguintes, o índice total foi de apenas $6,7 \%$, tendo sido um pouco maior entre as públicas $(7,6 \%)$. O fenômeno que mais chama a atenção é o do aumento menor do total das IES privadas $(6,6 \%)$, mas com crescimento seis vezes maior das IES com fins lucrativos $(37,7 \%)$ e uma importante redução do número das IES sem fins lucrativos ( $-18 \%)$. Isto deveu-se, como em grau menor na fase anterior (1999-2010), especialmente à aquisição e incorporação de IES sem fins lucrativos por IES com fins lucrativos. ${ }^{9}$

No período 1999-2018, destacam-se ainda os seguintes números: $131 \%$ de aumento do total de IES; 55,7\% de IES públicas; $147,3 \%$ de IES privadas, mas dentre estas, 958,1\% das com fins lucrativos contra apenas 21,6\% das sem fins lucrativos.

A tabela 8 mostra que a expansão das matrículas, no período 1999_ 2018, deu-se em índices percentuais ainda mais significativos que no caso das IES, tanto no aumento do total de matrículas quanto no total de matrículas públicas (especialmente nas IES federais) e privadas (especialmente das IES com fins lucrativos). Isto deveu-se, no caso das IES federais, ao Programa denominado Reuni (Programa de Apoio a Planos de Reestruturação e Expansão das Universidades Federais) implementado de 2007 a 2012, que praticamente dobrou o número de matrículas das IES federais neste período. No caso das IES privadas com fins lucrativos, deveu-se, de modo especial, à ampliação da oferta de cursos, pelo barateamento das mensalidades e pelo aumento da oferta da educação a distância (EaD).

Desta tabela 8 destacam-se alguns dados: 1) O aumento das matrículas, em praticamente todos os casos, foi percentualmente muito superior ao das IES; 2) O período de muito maior expansão foi o de 1999-2010 em relação ao de 2010-2018; 3) Para um crescimento das matrículas no período de 1999-2018 de $256 \%$, as públicas, mesmo as matrículas federais tendo alcançado 199\%, ficaram em 149\%, enquanto as privadas alcançaram 314\% e, destas, as das IES com fins lucrativos, chegaram a quase $2.000 \%(1.993,5 \%)$ contra apenas $58,9 \%$ das IES privadas sem fins lucrativos.

\footnotetext{
9 Para uma visão detalhada desses processos de compra, fusão, incorporação de IES pequenas por IES médias e de pequenas e médias por grandes, ver Sguissardi (2014).
} 


\section{Matrículas de graduação por sexo e cor/raça}

No estudo da evolução da educação superior, duas variáveis merecem ser ainda observadas: sexo e cor/raça. No caso da primeira, os censos de educação superior do Instituto Nacional de Estudos e Pesquisas (Inep), do MEC, têm fornecido dados para os três anos que tomamos como referências: 1999, 2010 e 2018. Quanto à segunda, cor/raça, somente encontramos dados do Inep para o ano 2018 e alguns outros dados esparsos de outras fontes.

Em relação ao gênero, como já assinalado quando se tratou das desigualdades sociais, as mulheres tendem a ter maior escolaridade que os homens. No caso da educação superior, a Tabela 9 abaixo mostra que, no período 1999_ 2018, as matrículas femininas foram superiores às masculinas numa variação de 11,2 a 14 pontos percentuais.

Tabela 9 - Matrículas de Cursos de Graduação por sexo dos matriculados Brasil - 1999-2018

\begin{tabular}{llllll}
\hline \hline \multirow{2}{*}{ Ano } & \multicolumn{5}{c}{ Matrículas em Cursos de Graduação } \\
\cline { 2 - 6 } & Total & Masculino & $\mathbf{0}$ & Feminino & $\mathbf{\%}$ \\
\hline \hline 1999 & 2.369 .945 & 1.051 .552 & $\mathbf{4 4 , 4}$ & 1.318 .393 & $\mathbf{5 5 , 6}$ \\
2010 & 5.449 .120 & 2.432 .816 & $\mathbf{4 4 , 6}$ & 3.016 .304 & $\mathbf{5 5 , 4}$ \\
\hline 2018 & 8.450 .755 & 3.633 .659 & $\mathbf{4 3 , 0}$ & 4.817 .096 & $\mathbf{5 7 , 0}$ \\
\hline \hline
\end{tabular}

Fonte: Sinopse Estatística do Ensino Superior de Graduação, 1999; INEP, 2000; Censo de Educação Superior, 2010; INEP, 2011; Instituto Nacional de Estudos e Pesquisas Educacionais Anísio Teixeira, 2019 (Elaboração nossa a partir dos dados do INEP’.).

Quanto à variável cor/raça e matrícula na educação superior, embora a participação de pardos e negros fosse próxima da dos brancos na composição populacional, em 2005, sua frequência à educação superior era cerca de três vezes menor: apenas 5,5\% dos jovens negros e pardos de 18 a 24 anos estavam matriculados nesse nível de educação contra 17,8\% dos jovens brancos dessa faixa etária.

Com a entrada em vigor da Lei 12.711/2012, das Cotas Sociais ${ }^{10}$, nas universidades públicas (especialmente federais), além de outras ações afirmati-

10 Esta lei obriga universidades, institutos e centros federais a reservarem $50 \%$ das vagas oferecidas em seus processos seletivos a candidatos com direito a cotas. A Lei de Cotas foi promulgada em 2012, mas algumas universidades (UnB, UERJ, UEMS e UNEB), cerca de 10 anos antes, já tinham aprovado legislação interna com sentido bastante similar ao que viria a ser objeto desta nova lei. 
vas, como bolsas, ajudas de custo para manutenção, houve um significativo crescimento da participação dos afrodescendentes na educação superior, em especial nas IES públicas: em 2015 já eram 12,8\% os jovens de 18 a 24 anos matriculados nesse nível de educação contra $26,5 \%$ de brancos.

Segundo dados do IBGE, entre 2000 e 2017 as chances de obtenção de um diploma de graduação para os jovens negros e pardos na graduação teriam se multiplicado quase cinco vezes, de $2,2 \%$, da população de 18 a 24 anos, para 9,3\%. Essa proporção entre os jovens brancos passou de 9,3\% em 2000 para 22\% em 2017 (SGUISSARDI, 2019).

Tabela 10 - Matrículas de Cursos de Graduação por cor/raça dos matriculados (autodeclarados) - Brasil - 2018

\begin{tabular}{|c|c|c|c|c|c|c|c|}
\hline \multirow{2}{*}{$\begin{array}{c}\text { Categoria } \\
\text { Administrativa }\end{array}$} & \multicolumn{7}{|c|}{ "Matrículas em Cursos de Graduação } \\
\hline & Total & Branca & $\%$ & $\begin{array}{l}\text { Pretos e } \\
\text { Pardos }\end{array}$ & $\%$ & $\begin{array}{l}\text { Não De- } \\
\text { clarado }\end{array}$ & $\%$ \\
\hline Brasil & 8.450 .755 & 3.533 .562 & 41,8 & 3.027 .572 & 35,8 & 1.660 .792 & 19,6 \\
\hline Públicas & 2.077 .481 & 835.915 & 40,2 & 840.360 & 40,4 & 333.947 & 16,7 \\
\hline Federais & 1.324 .984 & 500.664 & 37,8 & 606.617 & 45,8 & 175.067 & 13,2 \\
\hline Privadas & 6.373 .274 & 2.697 .647 & 42,3 & 2.187 .212 & 34,3 & 1.326 .845 & 20,8 \\
\hline
\end{tabular}

Fonte: Instituto Nacional de Estudos e Pesquisas Educacionais Anísio Teixeira, 2019 (elaboração do autor).

O Censo da Educação Superior 2018, do Inep (2019) traz dados que permitem verificar a frequência à educação superior por cor/raça. Embora o percentual de "não declarado" seja de quase 20\% (13,2\% nas IES federais e 20,8\% nas IES privadas), é possível levantar-se a hipótese de que a Lei de Cotas e demais ações afirmativas contribuíram para um avanço significativo em relação à participação de pretos e pardos no conjunto das matrículas da educação superior. Deixa-se de considerar nesta tabela o percentual de 1,6\% da cor/raça amarela e de $0,60 \%$ de indígenas.

Para as observações que se seguem é necessário lembrar que, em 2018, os brancos compunham em torno de $43 \%$ da população brasileira; os pretos e pardos, 55\%. Do total de 8.450.755 matriculados na educação superior 41,8\% declararam-se brancos e 35,8\%, pretos e pardos. Do total de 2.077 .481 matriculados em IES públicas, os autodeclarados pretos e pardos (40,4\%) superam levemente os autodeclarados brancos (40,2\%). Do total de 6.373 .274 matriculados em IES privadas, os autodeclarados brancos $(42,3 \%)$ superaram os autodeclarados pretos e pardos $(34,3 \%)$ em 8 pontos percentuais. Finalmente, do total 
de 1.324.984 matriculados nas IES federais, os autodeclarados brancos $(37,8 \%)$ foram superados pelos autodeclarados pretos e pardos $(45,8 \%)$ também, no sentido inverso, por 8 pontos percentuais. Neste caso, se os 13,2\% de "não declarados" fossem divididos de modo proporcional aos dados dos autodeclarados, chegar-se-ia a percentuais bastante próximos dos que alcança cada etnia na composição populacional.

Como se pode observar, a igualdade de condições de acesso à educação superior, uma das condições de democratização deste nível de educação, está ainda muito distante do esperado, embora aqui se vislumbre, através da Lei de Cotas e de outras ações afirmativas, formas e caminhos para se avançar nessa direção.

\section{Evolução da Taxa Líquida de Matrícula na Educação Su- perior}

Uma das formas de verificar a evolução da cobertura da ES é observar a denominada Taxa Líquida de Matrícula na ES da população de 18 a 24 anos. A tabela abaixo, que traz dados da Pnad (de 1992 a 2010) e do Censo da Educação Superior do Inep (2011 a 2018), permite verificar tal evolução.

Tabela 11 - Evolução da Taxa Líquida de Matrícula na Educação Superior Brasil - 1999-2018

\begin{tabular}{cccc}
\hline \hline ANO & $\begin{array}{c}\text { População de 18 a } \\
\text { 24 anos }\end{array}$ & $\begin{array}{c}\text { Matriculados de 18 } \\
\text { a 24 anos }\end{array}$ & $\begin{array}{c}\text { Taxa Líquida de } \\
\text { matriculados }\end{array}$ \\
\hline \hline $\mathbf{1 9 9 9}$ & 19.977 .857 & 1.567 .917 & 7,8 \\
$\mathbf{2 0 1 0}$ & 23.873 .786 & 3.188 .000 & 13,4 \\
\hline $\mathbf{2 0 1 8}$ & 22.786 .000 & 4.323 .580 & 19,0 \\
\hline \hline $\mathbf{1 9 9 9 - 2 0 1 0} \Delta \%$ & $\mathbf{1 9 , 5}$ & $\mathbf{1 0 3 , 3}$ & $\mathbf{7 1 , 8}$ \\
$\mathbf{2 0 1 0 - 2 0 1 8} \Delta \%$ & $-\mathbf{0 4 , 5}$ & $\mathbf{3 5 , 6}$ & $\mathbf{4 1 , 8}$ \\
\hline $\mathbf{1 9 9 9 - 2 0 1 8} \Delta \%$ & $\mathbf{1 4 , 0}$ & $\mathbf{1 7 5 , 7}$ & $\mathbf{1 4 3 , 6}$ \\
\hline \hline
\end{tabular}

Fonte: PNAD (1999, 2010 e 2018). Disponível em: <www.ibge.gov.br/estatisticas/sociais/educacao/9127-pesquisa-nacional-por amostra-de-domicilio.html $>$ e Sinopse Estatística do Censo da Educação Superior. Disponível em: < www.inep.gov.br/sinopses-estatisticas-da-educacao-superior> (Elaboração do autor e de Nelson C. Amaral)

Os dados da tabela 11 mostram que, apesar de um aumento bastante significativo da taxa líquida no período 1999-2018 em relação ao moderado crescimento da população da faixa etária de 18 a 24 anos (14\% versus 143,6\%), 
tal índice $(19 \%)$ está muito distante da meta prevista pelo Plano Nacional de Educação 2014-2024 que é de 33\%.

Por outro lado, a taxa bruta de matrícula ${ }^{11}$, em 2018, de 37,4\%, indica que praticamente metade dos matriculados na educação superior do país, nesse ano, estavam fora da faixa etária considerada adequada para esse nível de educação. E isto, em grande medida, em razão de desajustes série-idade.

O fato mais grave neste sentido dá-se em relação à população afrodescendente (pretos e pardos):

[...] na idade de frequentar a educação superior [18-24 anos], 52\% dos negros e pardos ainda estão cursando a educação básica (e, frequentemente, trabalhando), contra 29,1\% dos jovens brancos (SGUISSARDI, 2019, p. 21)

\section{Financiamento da educação superior e o Future-se}

Desde o impeachment/golpe da Presidente Dilma, a educação superior pública e privada, em especial no seu nível de pós-graduação e de sua dimensão de pesquisa, vem deixando de ter o grau de prioridade que vinha tendo nos governos anteriores a esse evento jurídico-político de 2016. Isto pode ser demonstrado se examinadas as medidas relativas ao financiamento, seja do Ministério de Ciência, Tecnologia, Inovação e Comunicações (MCTIC), ao qual está vinculado o Conselho Nacional de Pesquisa (CNPq); seja da Coordenação de Aperfeiçoamento de Pessoal de Nível Superior (CAPES), responsável pelo financiamento, regulação/avaliação e controle dos mais de 4.400 programas de pós-graduação de todas as IES de educação superior públicas e privadas; seja do capital e custeio da IES federais.

No caso do MCTIC, os cortes orçamentários reduziram-lhe as verbas para o ano de 2020 a $1 / 4$ das de seu orçamento de 2016. Sabendo-se que o CNPq "é responsável pelo financiamento de mais de 20 mil projetos de pesquisa ou 1/3 dos cerca de 60 mil projetos de pesquisa financiados pelas diferentes agências de financiamento nacionais e estrangeiras" (SGUISSARDI, 2020, p. 155), pode-se afirmar que prejuízo semelhante ao da execução desses proje-

\footnotetext{
11،A taxa bruta de matrícula (TBM) é definida como o total de pessoas que frequentam cursos superiores de graduação (independentemente da idade) em relação ao total da população em idade considerada adequada para cursar esse nível de ensino" (BRASIL, 2020).

12 Vide: <https://www1.folha.uol.com.br/ciencia/2019/08/sob-risco-de-colapso-cnpqfinancia-um-terco-da-ciencia-nacional.shtml>. Acesso em: 12 set. 2019
} 
tos deverá sofrer a produção científica publicada que decorre de tais projetos, isto é, "sem participação do CNPq a curto e médio prazos esta produção dificilmente veria a luz do dia" (Idem, ibidem).

A Lei Orçamentária para 2020 previa uma redução de 40\% nos recursos da Capes para seu funcionamento e pagamento de bolsas e auxílios em relação ao orçamento de 2019 (de mais ou menos R 4 bilhões para cerca de $\mathrm{R} \$ 2,3$ bilhões). Veja-se gráfico 4 abaixo. "Em 2020, o orçamento da Capes corresponderá a cerca de $25 \%$ do de $2015^{13}$, quando o número de programas de pósgraduação era de 2.057 contra os cerca de 4.300 atuais e o de mestrandos e doutorandos era de 163.671 contra os cerca de 400.000 atuais" (SGUISSARDI, 2020, p. 156).

Gráfico 4 - Orçamento da CAPES corrigido pelo IPCA (IBGE) com base em junho de cada ano.

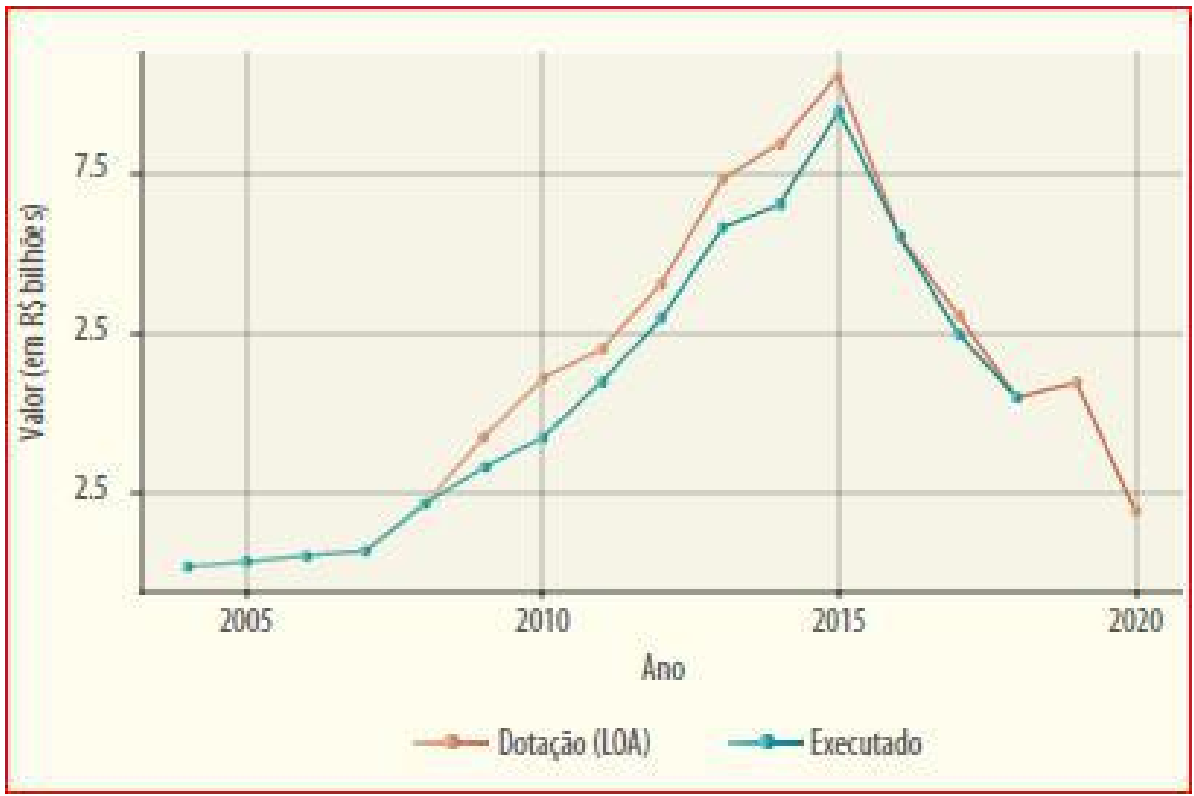

Fonte: <https://sintepiaui.org.br/noticia/442/O-orcamento-da-CAPES-para-2020com-a-LOAS-do-novo-governo $>$. Acesso em: 30 abr. 2020. Arte: Diagrama Editorial (SGUISSARDI, 2020, p. 156).

\footnotetext{
13 Vide < <ttps://www.nexojornal.com.br/grafico/2019/09/05/Qual-\%C3\%A9-o-or $\% \mathrm{C} 3 \% \mathrm{~A} 7 \mathrm{amento}-\mathrm{da}-\mathrm{Capes}-\mathrm{e}-\mathrm{O}-\mathrm{que}-\mathrm{ele}-$ representa-para-O-Brasil $>$
} 
O gráfico 5 mostra a evolução dos recursos das três principais fontes de financiamento de pesquisa e pós-graduação do país do ano 2000 a 2020. Em 2020 os recursos serão menores que os de 2006 e corresponderão a apenas $31,5 \%$ dos de 2015.

Gráfico 5 - Orçamento dos principais fundos de apoio à pesquisa científica e tecnológica no Brasil (FNDCT, CNPq e CAPES): 2000-2020 - [Valores totais previstas no Projeto de Lei Orçamentária Anual (PLOA) de cada ano, excluídas reservas de contingência].

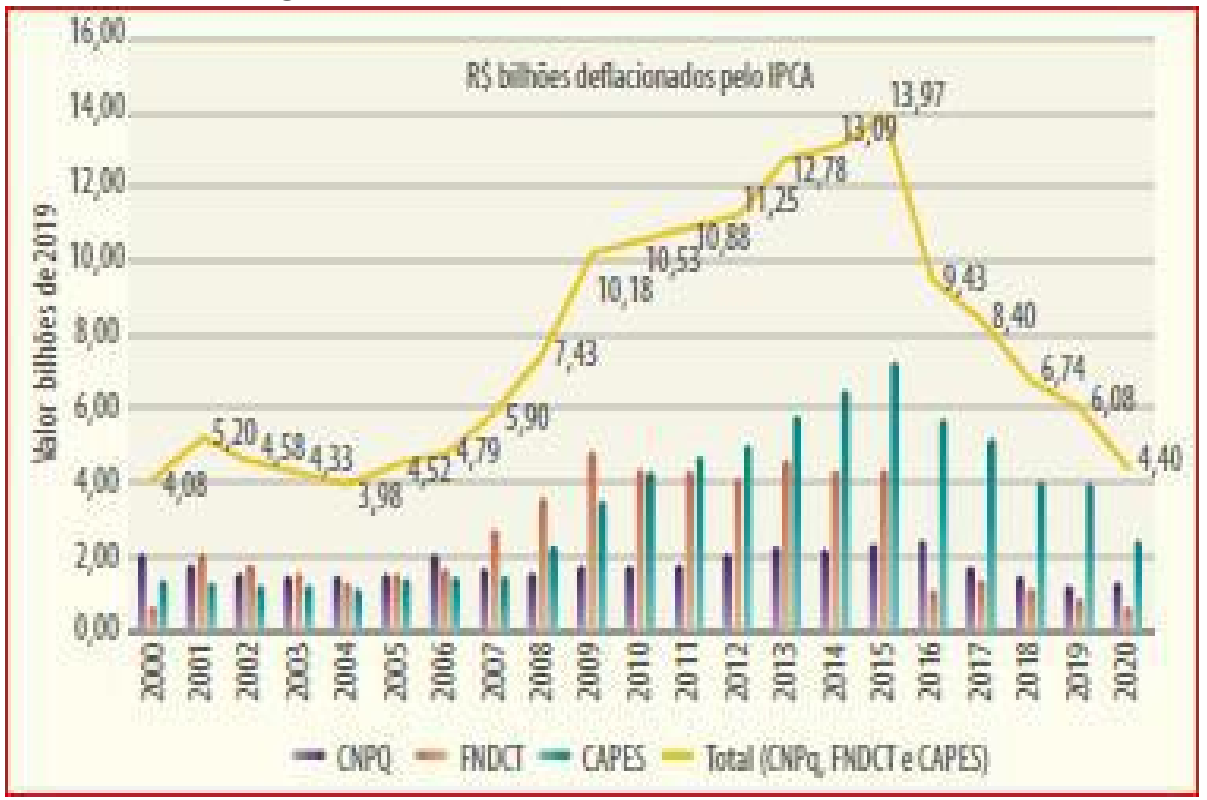

Fonte: <http://www.abc.org.br/2019/09/11/liquide-se/>. Acesso em: 30 abr. 2020. Arte: Diagrama Editorial (SGUISSARDI, 2020, p. 156).

A tabela 12 e o gráfico 6 mostram a evolução dos recursos de custeio e capital/investimento das universidades federais (incluídos os hospitais universitários) de 2003 a 2019. No caso do custeio, houve um crescimento constante no período 2003-2013; e, no caso do capital/investimento, no período 2003-2011.

A redução dos recursos para custeio inicia-se em 2014 e atinge seu menor valor em 2019, isto é, $-28 \%$ do valor de 2013. A redução, iniciada em 2012, mas agravada drasticamente a partir de 2015 , é a referente aos recursos de capital/investimento que atingem, em 2019, apenas 4,6\% do valor de 2011 ou uma redução de $95 \%$. 
Tabela 12 - Evolução das Despesas da União com as universidades federais em custeio e capital/investimento, incluídos os hospitais universitários, 2003-2020. Valores (R\$1,00) a preços de janeiro de 2020 (IPCA).

\begin{tabular}{|c|c|c|}
\hline & CUSTEIO & INVESTIMENTOS \\
\hline 2003 & 2.406 .419 .011 & 225.902 .062 \\
\hline 2004 & 2.984 .837 .531 & 313.934 .183 \\
\hline 2005 & 3.167 .364 .854 & 428.912 .289 \\
\hline 2006 & 3.511 .129 .594 & 612.907 .746 \\
\hline 2007 & 4.093 .093 .831 & 1.161.226.589 \\
\hline 2008 & 4.449 .583 .936 & 1.172.993.609 \\
\hline 2009 & 5.396 .034 .453 & 2.693 .813 .334 \\
\hline 2010 & 6.995 .387 .052 & 2.873 .072 .680 \\
\hline 2011 & 7.566 .516 .281 & 3.923.391.801 \\
\hline 2012 & 8.180 .429 .356 & 3.870 .578 .933 \\
\hline 2013 & 9.888 .804 .484 & 3.676 .725 .381 \\
\hline 2014 & 9.247 .946 .807 & 2.933 .436 .580 \\
\hline 2015 & 7.931 .202 .805 & 864.037 .764 \\
\hline 2016 & 8.174 .818 .013 & 755.018 .987 \\
\hline 2017 & 7.598 .729 .143 & 548.093 .079 \\
\hline 2018 & 7.521 .178 .890 & 344.139 .145 \\
\hline 2019 & 7.123 .033 .264 & 182.274 .168 \\
\hline $2011-2019 \Delta$ & $-05,8$ & $-95,4$ \\
\hline 2013-2019 $\Delta$ & $-28,0$ & $-95,0$ \\
\hline $2003-2019 \Delta$ & 196,0 & $-19,3$ \\
\hline
\end{tabular}

Fontes: Câmara dos Deputados, 2020 (elaboração de Epitácio Macário-UECE e do autor). 
Gráfico 6 - Evolução das Despesas da União com as universidades federais em custeio e capital/investimento (incluídos os hospitais universitários), 20032020. Valores $(\mathrm{R} \$ 1,00)$ a preços de janeiro de 2020 (IPCA).

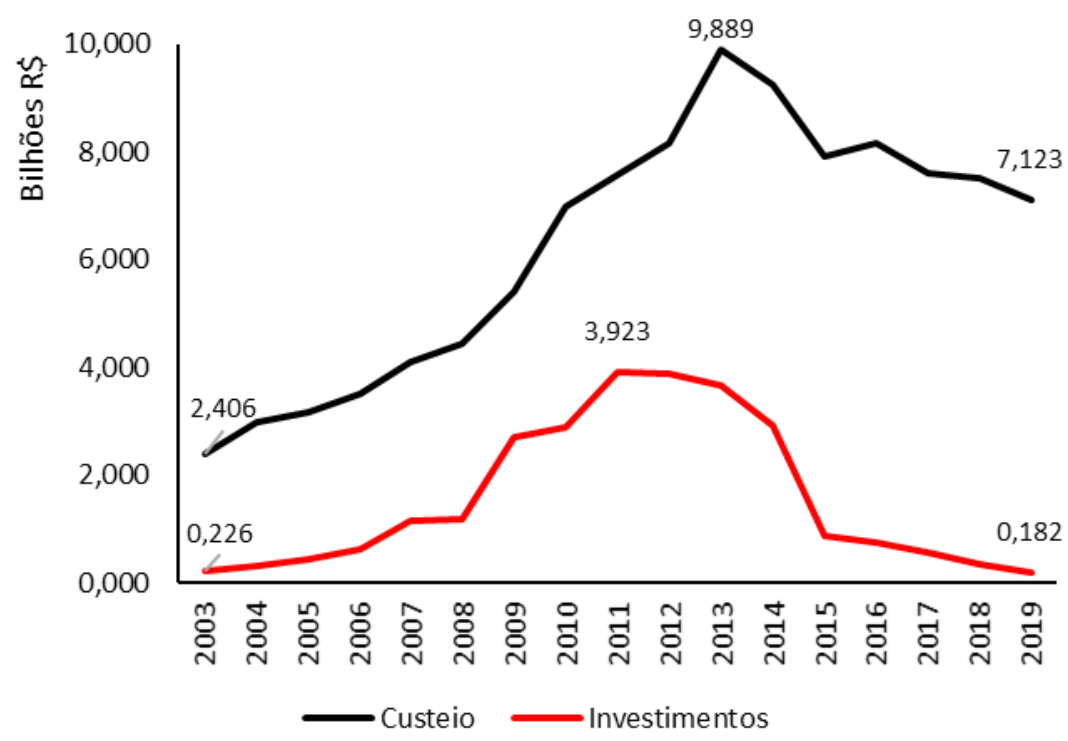

Fontes: Câmara dos Deputados, 2020 (elaboração de Epitácio Macário - UECE).

\section{Future-se}

Além da drástica redução do financiamento das IES federais, responsabilidade precípua do governo federal, via Ministério da Educação (MEC), como visto acima, tanto para seu "sistema" de 63 universidades e 40 Institutos Federais, como para as agências que financiam e regulam/avaliam e controlam a pós-graduação e a pesquisa vinculada à educação superior no país; dando continuidade aos desígnios da Emenda Constitucional 95, que congelou por 20 anos as despesas primárias do Poder Executivo Federal, entre as quais as destinadas à educação; e na mesma perspectiva "ultraliberal" da PEC 188/2019-Senado (resumidamente exposta na introdução deste texto), a obra-prima do atual governo, empossado em janeiro de 2019, em termos de proposta de intervenção nas IES federais tem sido a proposta denominada "Future-se".

Tendo como pano de fundo os princípios neoliberais da competição e concorrência a predominar em todos os âmbitos do Estado, do mercado e setores da sociedade; o saber como mercadoria, commodity, mercadoria-valor e as 
instituições de educação superior e de pesquisa como empresas produtoras de valor em que vigorem essas "virtudes" da concorrência e competitividade; tudo isso, aliado a um anti-intelectualismo, anticientificismo e anti-humanismo, conduziu à produção pelo MEC, sob o comando do segundo Ministro de Educação do Governo Bolsonaro, identificado com as concepções neoliberais extremadas do Ministro da Economia (Paulo Guedes), a partir de julho de 2019, em $1^{a}$ versão, em outubro, em $2^{a}$ versão, em janeiro de 2020 , em $3^{\text {a }}$ versão, e, em final de maio de 2020, em $4^{a}$ versão, a proposta do "Future-se", então transformada no Projeto de Lei (PL) n. 3076/2020 encaminhado ao Congresso Nacional,.

Resumidamente, essa proposta de reforma das IES federais visa transformar a estrutura e o funcionamento dessas instituições que, segundo a Cons tituição Federal de 1988, “[...] gozam de autonomia didático-científica, administrativa e de gestão financeira e patrimonial, e obedecerão ao princípio de indis sociabilidade entre ensino, pesquisa e extensão”, e que, segundo a Lei de Diretrizes e Bases da Educação Nacional (Lei 9.394/96), têm assegurado pela União, anualmente, "recursos suficientes para manutenção e desenvolvimento das instituições de educação superior por ela mantidas", em instituições que priorizariam três eixos de funcionamento: I - Pesquisa, desenvolvimento tecnológico e inovação; II - Empreendedorismo; III - Internacionalização.

Do conjunto das suas quatro versões pode-se deduzir: a) uma clara tendência a substituir a atual autonomia de gestão financeira das IES federais por uma suposta autonomia financeira, e substituir, ao menos parcialmente, as atuais atribuições das reitorias na administração e gestão financeira dessas instituições pela adesão - voluntária? - ao "Future-se" via "celebração de contrato de resultado" entre cada Ifes e o MEC (União); b) que o reiterado apelo à pes quisa tecnológica que produza inovação ${ }^{14}$, que, no espírito do "Future-se", poderia ser definida como "[...] invenção rentável seguramente e acurto prazo" para o mercado (OLIVEIRA, 2019, p. 2, grifo do autor) e o uso abusivo dos termos empreendedor/a/es/as e empreendedorismo ${ }^{15}$ deixam evidente a concepção empresarial que comandou essa proposta de reforma; c) que, a depender do peso do "Future-se" no conjunto das atividades de pesquisa das Ifes, pode-se afirmar que as atividades de ensino e pesquisa nas áreas de ciências sociais, humanidades, artes, assim como a própria pesquisa básica e a extensão universitá-

\footnotetext{
14 A palavra inovação foi utilizada 32 vezes na proposta do PL em suas 16 páginas.

15 Esses termos foram utilizados 36 vezes na proposta do PL.
} 
ria, correm sérios riscos de subfinanciamento, desprestígio e desestímulo (SGUISSARDI, 2020).

Por último, cabe dizer que o PL 3076 - $4^{a}$. versão - deixou de defender a utilização das Organizações Sociais como espinha dorsal da administração financeira das IFES em que se apoiariam diversos tipos de contratos, como preconizavam versões anteriores, para agora reforçar a presença e a atribuição das Fundações de Apoio Institucional (privadas e já existentes). Na avaliação de Roberto Leher,

Entretanto, o PL, como o escorpião da fábula, não pode ocultar sua natureza bolsonarista: está inscrito na guerra cultural, é hostil à ciência, à autonomia universitária e à liberdade de cátedra e reafirma a definição estratégica de refuncionalização das instituições em "organizações" empreendedoras e inovadoras em um ambiente produtivo em que, regra geral, a pesquisa e desenvolvimento (P\&D) é escassa, desprovida de originalidade e minguante. Por meio dessas adjetivações (empreendedora e inovadora), almeja mudanças na função social das universidades frente aos problemas dos povos, aos desafios democráticos - políticos e econômicos - da nação e aos problemas lógicos e epistemológicos do conhecimento. Ao tentar aprisionar a universidade como organização utilitarista, objetiva suprimir, radicalmente, a liberdade de cátedra (LEHER, 2020).

Leher responde, também, por que é proposto um PL desta natureza e da forma como o foi:

O PL é feito para moldar o orçamento do MEC às restrições da "lei de ferro" instituída pela EC 95/2016 que, em virtude da crise, serão ainda mais draconianas (...) Ou seja, em virtude das restrições estabelecidas pela EC 95, a alternativa [oferecida pelo Future-se...] é a captação no mercado, como se isso fosse desejável e possível" (LEHER, 2020).

Como se isso fosse manter a universidade autônoma no ensino, pesquisa e extensão...

\section{Considerações finais}

Neste texto, de forma sucinta, visou-se mostrar, com uma série de dados empíricos e exemplos vários, a vigência de concepções e práticas políticas e 
econômicas neoliberais no país que contribuem decisivamente para a produção e aumento da desigualdade social, assim como para, de alguma forma, retardar a democratização da educação superior.

Quanto às concepções e práticas neoliberais e "ultraliberais", os exemplos citados das Emendas Constitucionais e Leis aprovadas pelo Congresso Nacional, desde o impeachment/golpe de 2016 até a presente data de 2020, e o teor de ao menos uma das PEC's em tramitação no $\mathrm{CN}$, de iniciativa do Poder Executivo e de parlamentares, acredita-se que são suficientes para demonstrar o fortalecimento do poder de exploração do trabalho da classe político-empresarial dominante e a destruição dos direitos dos trabalhadores arduamente conquistados ao longo de décadas de lutas reivindicatórias destes. As reformas trabalhista e da previdência social são representativos do que vem de ser dito.

Quanto ao quadro da extrema e crescente desigualdade social brasileira, a afirmação do relatório da Oxfam-Brasil, acima exposta em epígrafe deste item, ilustra bem o que outros diversos indicadores de organismos nacionais e multilaterais apontam e detalham sobre a realidade grave dessa desigualdade, com tendência de agravar-se ainda mais, caso tenham continuidade as políticas neoliberais extremadas em curso no país.

Muitos outros aspectos, além dos expostos, poderiam ser destacados para mostrar a gravidade da desigualdade social brasileira. Entretanto, os destaques que se deu ao rendimento domiciliar per capita (2012-2018), à desigualdade de ocupação e renda entre homens e mulheres, entre brancos e afrodescendentes, entre outros, serviram para ilustrar por que o Brasil fica apenas atrás do Catar, como país que apresenta "[...] a segunda maior concentração de renda do mundo".

Com o segundo item deste texto - "Desigualdade social e a educação superior no Brasil" - visou-se apresentar alguns elementos que demonstrassem o que se propôs como objetivo deste artigo, isto é, mostrar que este nível da educação continua a manter, nas últimas décadas e especialmente desde o impeachment presidencial de 2016, uma bastante estreita relação com a imensa desigualdade social no país e, assim, eventualmente, a reproduzi-la e a contribuir para, a seu modo, agravar a ausência de efetiva democracia na sociedade brasileira que se traduz, especialmente, por essa crescente desigualdade.

Enfatizou-se, após, a apresentação deste objetivo para este breve estudo, que não é democrática uma sociedade em que são incomensuráveis as desigualdades sociais e infinitas as diferenças de oportunidades, por exemplo, de acesso à ES dos indivíduos pertencentes às suas diferentes classes sociais. E que 
o acesso à ES de apenas $1 / 5$ da população de 18 a 24 anos não dependia fundamentalmente de disposição/vontade familiar ou pessoal, mas, sim, de absoluta ausência de condições socioeconômicas da imensa maioria da população.

Isso é facilmente demonstrável pelos dados apresentados no item 1 Uma amostra da imensa desigualdade social brasileira - mas, especialmente, pela evolução da Taxa Líquida de Matrícula na ES (Tabela 11), pelos índices alcançados pelo processo de privado-mercantilização da educação superior (Tabelas 7 e 8), entre outros. Na tabela 11, mostra-se que se, em 1999, as IES privadas com fins de lucro eram $12,4 \%$ do total, em 2018 , elas já eram $51 \%$ ou 1.303 das 2.537 IES do país. E que somadas às 935 (36,8\%) IES privadas sem fins lucrativos perfazem 2.238 ou $88,2 \%$ do total de IES do país. Como as IES públicas e gratuitas são apenas 11,8\% (já foram 27,1\% em 1985 e 17,5\% em 1999) do total e de alta concorrência nos seus exames seletivos de entrada, restam para a maioria da população de 18 a 24 anos, a maioria oriunda da escola média pública, as outras 2.238 IES privadas com ou sem fins lucrativos, mas todas pagas e em geral de menor qualidade que as IES públicas.

Apesar de a proporção de matrículas públicas e privadas ser diferente da proporção do número de instituições, dado que entre as IES públicas predominam as organizadas como universidades (Tabela 8), também neste caso, a tendência de crescimento menor no número de matrículas públicas do que das privadas se verifica ao longo das últimas décadas: em 1985, as matrículas públicas eram 40,7\%; em 1999, 35,1\%; e, em 2018, 24,6\%. O inverso ocorria com as matrículas privadas, que passaram de 59,3\% em 1985 a 75,4\% em 2018, com destaque para as matrículas em IES com fins lucrativos, que passaram de $8,5 \%$ em 1999 a 50,2\% do total em 2018.

Vale destacar ainda dois fatos: 1) o de que as mulheres há várias décadas são uma maioria significativa na educação superior (Tabela 9), o que, entretanto, como visto, não tem impedido que no mercado de trabalho tenham índices de desocupação e de renda de cerca de 40\% menores do que os homens; 2 ) o de que os pretos e pardos, com a Lei de Cotas e outras ações afirmativas, es tão começando a ver reconhecido seu direito de igualdade de acesso à ES, a começar pelas IES federais (Tabela 10), ainda que faltem estudos para verificar se existem avanços na permanência (escolha das profissões) e disputa dos titulados no mercado de trabalho.

Finalmente, a relação da educação superior, em especial da educação superior pública, da pós-graduação e da pesquisa com a reprodução, diminuição ou ampliação da desigualdade social pode ser medida pela prioridade ou 
não prioridade que se lhe confere quando das decisões orçamentárias e propostas de reforma. Entre estas estão os cortes orçamentários do MCTIC (que inclui o CNPq) e da CAPES (Gráficos 4 e 5), as despesas da União de custeio e capital para as universidades federais (Tabela 12) assim como propostas como a do PL 3076/2020 (Future-se).

Para concluir e parafraseando a afirmação de mestre Anísio em epígrafe do item 2 deste texto, dir-se-á que somente haverá efetivos avanços na democratização do país no dia em que se diminua sua imensa desigualdade social, se universalize a educação básica, incluído o ensino médio, e se democratize o acesso, a permanência na educação superior e o acesso ao mercado de trabalho, dos titulados, sem discriminação de qualquer natureza.

\section{Referências}

AMARAL, N. C. A dimensão ultraliberal do grupo no poder federal está expressa na PEC 188/2019-Senado - Um desastre para as políticas sociais brasileiras. In: GIOLO, J.; LEHER, R.; SGUISSARDI, V. Future-se [recurso eletrônico]: ataque à autonomia das instituições federais de educação superior e sua sujeição ao mercado. São Carlos: Diagrama Editorial, 2020. p. 197-223. AMORIM, D. Desigualdade de renda é recorde em 2019, mas índice teve melhora no fim do ano. O Estado de S. Paulo, São Paulo, 14 fev. 2020. Disponível em: < https://economia.estadao.com.br/noticias/geral,desigualdade-derenda-e-recorde-em-2019-mas-indice-teve-melhora-no-fim-doano,70003198033\#: :text $=\mathrm{Na} \% 20$ s $\%$ C3\%A9rie $\% 20$ anual $\% 2 \mathrm{C} \% 20$ iniciada $\% 20$ em,escala $\% 20$ de $\% 200 \% 20 a \% 201>$. Acesso em: 15 set. 2020.

ANÍSIO TEIXEIRA, apud ROITMAN, 2016, TEIXEIRA, A, apud ROITMAN, Isaac. Educação pública é a melhor forma de consolidar a democracia. UOL, 01 mai. 2016. Disponível em: < https://noticias.uol.com.br/opiniao/coluna/2016/05/01/educacao-publica-boa-e-a-melhor-forma-de-consolidara-democracia.htm> Acesso em: 20 set. 2020.

BRASIL. Constituição (1988). Constituição da República Federativa do Brasil. Brasília: Senado, 1988.

. Lei n. 9.394, de 20 de dezembro de 1996. Estabelece as diretrizes e bases da educação nacional. D.O.U. de 23.12.1996. Disponível em: < http:// www.planalto.gov.br/ccivil_03/leis/19394.htm> Acesso em: 20 set. 2020. 
Lei n. 10.172, de 9 de janeiro de 2001. Aprova o Plano Nacional de Educação e dá outras providências. D.O.U. de 10.01.2001. Disponível em: http://www.planalto.gov.br/ccivil_03/leis/leis_2001/110172.htm Acesso em: 20 set. 2020.

Emenda Constitucional no 95, de 15 de dezembro de 2016. Altera o Ato das Disposições Constitucionais Transitórias, para instituir o Novo Regime Fiscal, e dá outras providências. Diário Oficial da União, Brasília, DF, 15 dez. 2016. Disponível em: <http://www.planalto.gov.br/ccivil_03/Constituicao/ Emendas/Emc/emc95.htm>. Acesso em: 24 set. 2019.

. Lei $\mathrm{n}^{\circ}$ 13.429, de 31 de março de 2017. Altera dispositivos da Lei ${ }^{\circ}$ 6.019/1974, que dispõe sobre o trabalho temporário, e versa sobre as relações de trabalho na empresa de prestação de serviços a terceiros. Diário Oficial da União, Brasília, DF, 31 mar. 2017a. Disponível em: <http://www.planalto.gov.br/ccivil_03/_ato2015-2018/2017/lei/L13429. htm>. Acesso em: 24 set. 2019.

. Lei no 13.467 , de 13 de julho de 2017. Altera a Consolidação das Leis do Trabalho (CLT), aprovada pelo Decreto-Lei $\mathrm{n}^{\circ} 5.452$, de $1^{\circ}$ de maio de 1943, e as Leis $n^{\circ}$ 6.019, de 3 de janeiro de 1974, n 8.036, de 11 de maio de 1990, e no 8.212, de 24 de julho de 1991, a fim de adequar a legislação às novas relações de trabalho. Diário Oficial da União, Brasília, DF, 14 jul. 2017b. Disponível em: <http://www.normaslegais.com.br/legislacao/Lei-134672017.htm>. Acesso em: 24 set. 2019.

. Instituto Nacional de Estudos e Pesquisas Educacionais Anísio Teixeira. Relatório do $3^{\circ}$ ciclo de monitoramento das metas do Plano Nacional de Educação - 2020 [recurso eletrônico]. - Brasília: Instituto Nacional de Estudos e Pesquisas Educacionais Anísio Teixeira, 2020. Disponível em: < http://portal.inep.gov.br/informacao-da-publicacao/-/asset_publisher/ 6JYIsGMAMkW1/document/id/6974122>. Acesso em: 6 jan. 2021.

Decreto n. 2.306, de 19 de agosto de 1997. Regulamenta, para o Sistema Federal de Ensino, as disposições contidas no art. 10 da Medida Provisória $\mathrm{n}^{\mathrm{o}} 1.477-39$, de 8 de agosto de 1997, e nos arts. 16, 19, 20, 45, 46 e $₫ 1^{\circ}$, 52, parágrafo único, 54 e 88 da Lei no 9.394, de 20 de dezembro de 1996, e dá outras providências. Disponível em: < http://www.planalto.gov.br/ccivil_03/ decreto/D2306impressao.htm>. Acesso em: 20 set. 2020.

. Ministério da Educação. Gabinete do Ministro Portaria Normativa No 40, de 12 De Dezembro de 2007. Institui o e-MEC, sistema eletrônico de 
fluxo de trabalho e gerenciamento de informações relativas aos processos de regulação da educação superior no sistema fedral de educação. Disponível em: $<$ https://download.inep.gov.br/download/condicoes_ensino/2007/ Portaria_n40.pdf $>$. Acesso em: 20 set. 2020.

MEC/INEP, Censo da Educação Superior. Microdados do Censo da Educação Superior, 1999, 2010 e 2018. Disponível em: < https://www.gov.br/ inep/pt-br/acesso-a-informacao/dados-abertos/microdados/censo-da-educacao-superior> Acesso em 20 set. 2020.

MEC/INEP. Sinopse Estatística do Ensino Superior de Graduação 1999. Disponível em: < https://download.inep.gov.br/download/censo/ 1999/superior/miolo1_Sinopse_Superior99.pdf>. Acesso em: 20 set. 2020.

. MEC/INEP. Sinopse Estatística da Educação Superior de Graduação 2010. Disponível em: < http://inep.gov.br/sinopses-estatisticas-da-educacao-superior $>$. Acesso em: 20 set. 2020.

. MEC/INEP. Sinopse Estatística da Educação Superior de Graduação 2018. Disponível em: < http://inep.gov.br/sinopses-estatisticas-da-educacao-superior>. Acesso em: 20 set. 2020.

. Lei n. 12.711, de 29 de agosto de 2012. Dispõe sobre o ingresso nas universidades federais e nas instituições federais de ensino técnico de nível médio e dá outras providências. DOU de 30.8.2012. Disponível em: < http:// www.planalto.gov.br/ccivil_03/_ato2011-2014/2012/lei/ 112711.htm\#: :text $=$ Disp $\% C 3 \% B 5 e \% 20$ sobre $\% 200 \% 20$ ingresso $\% 20$ nas, $m$ $\% \mathrm{C} 3 \%$ A 9 dio $\% 20 \mathrm{e} \% 20 \mathrm{~d} \% \mathrm{C} 3 \% \mathrm{~A} 1 \% 20$ outras $\% 20$ provid $\% \mathrm{C} 3 \%$ AAncias.>. Acesso em: 20 set. 2020.

MEC/INEP. Sinopse Estatística da Educação Superior de Graduação 2018. Disponível em: < http://inep.gov.br/sinopses-estatisticas-da-educacao-superior $>$. Acesso em: 20 set. 2020.

. MEC/INEP. Sinopse Estatística da Educação Superior de Graduação 2018. Disponível em: < http://inep.gov.br/sinopses-estatisticas-da-educacao-superior $>$. Acesso em: 20 set. 2020

. Instituto Nacional de Estudos e Pesquisas Educacionais Anísio Teixeira. Relatório do $3^{\circ}$ ciclo de monitoramento das metas do Plano Nacional de Educação - 2020 [recurso eletrônico]. - Brasília: Instituto Nacional de Estudos e Pesquisas Educacionais Anísio Teixeira, 2020. Disponível em: < 
http://portal.inep.gov.br/informacao-da-publicacao/-/asset_publisher/ 6JYIsGMAMkW1/document/id/6974122>. Acesso em: 6 jan. 2021.

Constituição da República Federativa do Brasil de 1988. Disponível em: < http://www.planalto.gov.br/ccivil_03/constituicao/ constituicao.htm>. Acesso em: 20 set. 2020.

Lei n. 9.394, de 20 de dezembro de 1996. Estabelece as diretrizes e bases da educação nacional. D.O.U. de 23.12.1996. Disponível em: < http:// www.planalto.gov.br/ccivil_03/leis/19394.htm>. Acesso em: 20 set. 2020.

. Congresso Nacional. Projeto de Lei (PL) n. 3076/2020. Institui o Programa Universidades e Institutos Empreendedores e Inovadores - Futurese. Disponível em: < https://www.camara.leg.br/proposicoesWeb/fichadetramitacao?idProposicao=2254321 > . Acesso em: 20 set. 2020 .

BRASIL ECONÔMICO, 2018a. Falta trabalho para 27,6 milhões de pessoas no Brasil, segundo pesquisa do IBGE. Disponível em: $<$ https://economia.ig.com.br/2018-08-16/falta-trabalho-indicador.html>. Acesso em: 20 set. 2020.

2018b. Mesmo estudando mais, mulheres ganham menos do que homens no mercado de trabalho. Disponível em: <https://economia.ig.com.br/ 2018-03-07/mercado-trabalho-homens-mulheres.html> . Acesso em: 20 set. 2020.

2018c. Salário mínimo ideal em fevereiro deveria ser de $\mathrm{R} \$ 3.682$, diz Dieese. Disponível em: <https://economia.ig.com.br/financas/2018-03-06/ salario-minimo-dieese.html> . Acesso em: 20 set. 2020.

CÂMARA DOS DEPUTADOS. Orçamento da União: Execução Orçamentária e Financeira da União (2003-2019). Disponível em: <https://www2.camara.leg.br/orcamento-da-uniao>. Acesso em: 27 jan. 2020.

COSTA, F. N. Brasil: País de Renda Per Capita Média com Poucos "Muito Rico" e Muitos "Muito Pobre”. Blog Cidadania \& Cultura. Disponível em: $<$ https://fernandonogueiracosta.wordpress.com/2017/10/30/brasil-pais-derenda-per-capita-media-com-poucos-muitos-ricos-e-muitos-muitos-pobres/>. Acesso em: 20 set. 2020

G1.GLOBO.COM, 2019. Disponível em: <https://g1.globo.com/mundo/noticia/2019/12/09/brasil-perde-uma-posicao-em-ranking-do-idh.ghtml>. Acesso em: 20 set. 2020

IBGE - Pesquisa Nacional por Amostra de Domicílios Contínua trimestral (2020). Disponível em: < https://www.ibge.gov.br/estatisticas/sociais/rendi- 
mento-despesa-e-consumo/9171-pesquisa-nacional-por-amostra-de-domicilios - continua - mensal.html? $=\& \mathrm{t}=$ series - historicas $>$. Acesso em: 03 ago. 2020.

. Síntese de Indicadores Sociais. Disponível em: <www.ibge.gov.br/estatisticas/sociais/populacao/9221-sintese-de-indicadores-sociais.html? edicao $=18830 \& \mathrm{t}=$ download $>$. Acesso em: 20 set. 2020.

INEP - Instituto Nacional de Estudos e Pesquisas Educacionais. Sinopse Estatística do Ensino Superior de Graduação 1999. Brasília: Inep, 2000. Disponível em: <http://download.inep.gov.br/download/censo/2000/Superior/ sinopse_superior-2000.pdf >. Acesso em: 15 ago. 2020.

. Censo de Educação Superior 2010. Brasília: Inep, 2011. Disponível em: <http://download.inep.gov.br/educacao_superior/censo_superior/documentos/2010/divulgacao_censo_2010.pdf>. Acesso em: 15 ago. 2020.

INSTITUTO NACIONAL DE ESTUDOS E PESQUISAS EDUCACIONAIS ANÍSIO TEIXEIRA. Sinopse Estatística da Educação Superior 2018. Brasília: Inep, 2019. Disponível em: < http://portal.inep.gov.br/basicacenso-escolar-sinopse-sinopse>. Acesso em: 15 ago. 2020.

IPEA. Atlas da Violência 2020 - Principais Resultados. Diretoria de Estudos e Políticas do Estado, das Instituições e da Democracia - Diest Fórum Brasileiro de Segurança Pública (FBSB), 2020. Disponível em: < https://www.ipea.gov.br/atlasviolencia/download/27/atlas-da-violencia-2020-principais-resultados >. Acesso em: 28 ago. 2020.

LEHER, R. O Cerco Está Sendo Fechado - Esboço de análise sobre o Projeto de Lei do Future-se. Le Monde Diplomatique. Disponível em: <https://diplomatique.org.br/projeto-de-lei-do-future-se/>. Acesso em: 19 jun. 2020.

OLIVEIRA, M. B. Universidade: por trás do projeto Weintraub. Outras Palavras. Disponível em:

$<$ https://outraspalavras.net/crise-brasileira/universidade-por-tras-do-projeto-weintraub/?

fbclid=IwAR291xH7qBfmspE_1wknAPw9J5A9_sTYQPN3W6xc6IJUmmP7s7fAVk8L0KU>. Acesso em: 28 jul. 2019. 
OXFAM BRASIL. A distância que nos une. Abr. 2019. Disponível em: < https://www.oxfam.org.br/um-retrato-das-desigualdades-brasileiras/a-distancia-que-nos-une/>. Acesso em: 20 set. 2020.

PNAD. Estatísticas sociais. 2018. Disponível em: < https://agenciadenoticias.ibge.gov.br/agencia-sala-de-imprensa/2013-agencia-de-noticias/releases/ 24857-pnad-continua-2018-educacao-avanca-no-pais-mas-desigualdadesraciais-e-por-regiao-persistem>. Acesso em: set. 2020.

REVISTA RETRATOS, n 11, maio de 2018. IBGE mostra as cores da desigualdade. Disponível em: <https://agenciadenoticias.ibge.gov.br/agencia-noticias/2012-agencia-de-noticias/noticias/21206-ibge-mostra-as-cores-da-desigualdade >. Acesso em: 06 fev. 2019.

RIGUETTI, S.; GAMBA, E. Sob risco de colapso, CNPq financia um terço da ciência nacional. Folha de S. Paulo, 26 ago. 2019. Disponível em: <https:// www1.folha.uol.com.br/ciencia/2019/08/sob-risco-de-colapso-cnpq-financia-um-terco-da-ciencia-nacional.shtml>. Acesso em: 20 set. 2020.

SGUISSARDI, V. Estudo Diagnóstico da Política de Expansão da (e Acesso à) Educação Superior no Brasil - 2002-2012. Brasília: Edital N. 051/2014 SESU; Projeto de Organismo Internacional - OEI; Projeto OEI/BRA/10https:// agenciadenoticias.ibge.gov.br/agencia-noticias/2012-agencia-de-noticias/noticias/21206-ibge-mostra-as-cores-da-desigualdade/002, 2014 (Ed. revisada em outubro de 2020).

Die Hochschulbildung ultraliberaler Zeiten in Brasilien. Ungleichheit, Vermarktung und Herausforderungen für die staatlichöffentliche Regulierung. In: GRUSCHKA, A.; LASTÓRIA, L. A. C. N. (Hrsg.). Zur Lage der Bildung Kritische Diagnosen aus Deutschland und Brasilien. Berlin: Verlag Barba Budrich, 2015. p. 93-109.

. A desigualdade social como fator determinante da exclusão educacional. Prefácio. In: SOUSA, A. S. Q.; MACIEL, C. E. (Org.) Desafios da educação superior: acesso, permanência e inclusão. 1. ed. Curitiba: CRV, 2019.

. Future-se - Um projeto neoliberal de heteronomia das Federais e um passo a mais rumo a sua privado/mercantilização. In: GIOLO, J.; LEHER, R.; SGUISSARDI, V. Future-se [recurso eletrônico]: ataque à autonomia das instituições federais de educação superior e sua sujeição ao mercado. São Carlos: Diagrama Editorial, 2020. p. 153-196. 
SOUZA, C.; ZANLORENZZI, G. Qual o orçamento da Capes e o que ele representa para o Brasil. NEXOJORNAL, 5 set. 2019. Disponível em:

$<$ https://www.nexojornal.com.br/grafico/2019/09/05/Qual-\%C3\%A9-O-or $\% \mathrm{C} 3 \% \mathrm{~A} 7$ amento-da-Capes-e-O-que-ele-representa-para-o-Brasil $>$. Acesso em: 20 set. 2020 . 